\title{
The Emerging Legal Architecture for Social Justice
}

\author{
Luz E. Herrera \\ Texas A\&M University School of Law, herrera@law.tamu.edu \\ Louise G. Trubek \\ Wisconsin Law School
}

Follow this and additional works at: https://scholarship.law.tamu.edu/facscholar

Part of the Law and Race Commons, Legal Education Commons, Legal Profession Commons, and the Public Law and Legal Theory Commons

\section{Recommended Citation}

Luz E. Herrera \& Louise G. Trubek, The Emerging Legal Architecture for Social Justice, 44 N.Y.U. Rev. L. \& Soc. Change 355 (2020).

Available at: https://scholarship.law.tamu.edu/facscholar/1427

This Article is brought to you for free and open access by Texas A\&M Law Scholarship. It has been accepted for inclusion in Faculty Scholarship by an authorized administrator of Texas A\&M Law Scholarship. For more information, please contact aretteen@law.tamu.edu. 


\title{
THE EMERGING LEGAL ARCHITECTURE FOR SOCIAL
}

\section{JUSTICE}

\author{
LUZ HERRERA $^{\infty}$ AND LOUISE G. TRUBEK ${ }^{\infty}$
}

\begin{abstract}
Lawyers advocating for social change are now front and center in newspapers and social media. This Article discusses how a new breed of progressive lawyers envision social justice law practice today. These lawyers, who we refer to as 'critical lawyers,' are diverse in background, gender, ethnicity and race. They see law as a complex, contradictory tool rather than a necessary and sufficient route to justice. Their practices differ from the traditional nonprofit public interest firms of the earlier generation that assumed that making law and lawyers accessible would lead to justice. To highlight the differences, the Article discusses the law practices of Beyond Legal Aid, Law for Black Lives, and TIME's UP. Beyond Legal Aid is redesigning legal services to produce community partnerships. Law for Black Lives provides legal services to ensure greater equity in criminal procedures. TIME's UP is radically revising how women respond to sexual harassment at the workplace. These practices seek to democratize the use of law to advance social justice by developing community and client collaborations. They rely on revenue from many sources including client fees, small donations through on-line platforms, and volunteer expertise. They seek to develop structures that can provide sustainability, flexibility, and growth including nodes and networks models that allow linkages across varied practice sites. This new architecture requires support from a variety of sources, including law schools and peer support groups - all of which enable the sharing of ideas and innovations.
\end{abstract}

$\infty$ Luz E. Herrera is a Professor and Associate Dean for Experiential Education at Texas A\&M University School of Law. Her clinical work focuses on community development and entrepreneurship. She founded Community Lawyers, Inc., a nonprofit organization in Compton, California. Much of her scholarship focuses on how lawyers integrate more entrepreneurial ideas to engage in public interest work.

$\infty$ Louise Trubek is Clinical Professor of Law Emerita at the University of Wisconsin Law School. She served as Adjunct Professor of Law at Seton Hall Law School 2010-12. For many years, she was the Executive Director and Clinical Director at the Center for Public Representation in Madison, Wisconsin. Her scholarship focuses on public interest lawyering, clinical legal education and poverty law. Our thanks to our excellent research assistants Nayelly Dominguez and Teresa Reyes-Flores. We also acknowledge Claire Brown for her input. Much gratitude to our excellent editors at the NYU Review of Law and Social Change, Sean Chang, Efosa Akenzua and Matthew Stolz. We are also deeply grateful to Sameer Ashar and David M. Trubek for their detailed comments and support. 


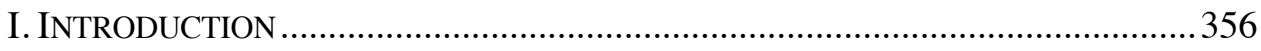

II. HISTORY AND DRIVERS OF THE CONTEMPORARY ENVIRONMENT ................362

A. The Early Public Interest Law: Legal Liberalism and its Discontents .......362

1. The Bright Line Between Law \& Politics .................................................. 364

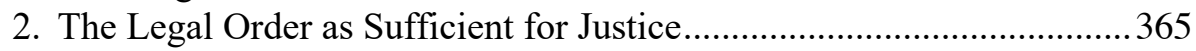

3. Heroic Role of Lawyers .......................................................................... 366

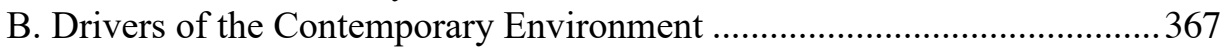

1. Shifting Demographics in the Legal Profession..................................... 368

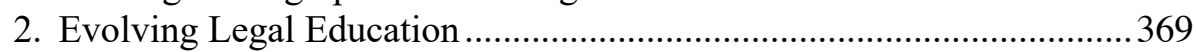

3. Incorporating New Tools in Legal Practice ......................................... 370

III. DEMOCRATIZING SOCIAL JUSTICE LAW PRACTICE ....................................... 373

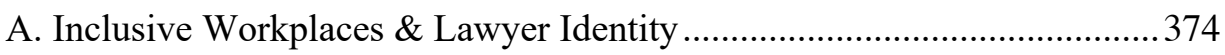

B. Community \& Client Collaborations ......................................................... 376

C. Sustainability through Social Entrepreneurship.......................................... 380

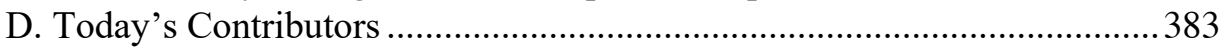

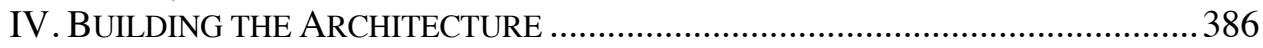

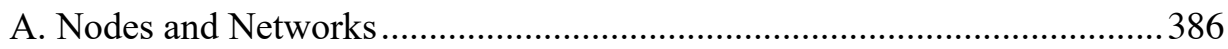

B. Fostering Growth and Innovation .......................................................... 388

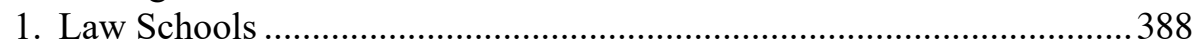

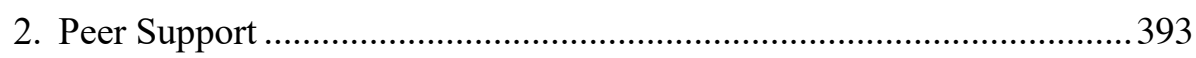

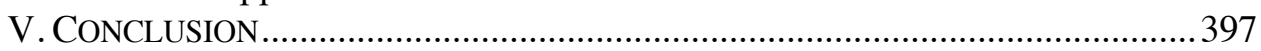

I.

INTRODUCTION

The publicity generated by lawyers' resistance to the Trump administration has again brought lawyers to the nation's attention as defenders of justice. People chanted, "let the lawyers in" at airports across the country after the enactment of the travel ban against individuals from seven Muslim countries. ${ }^{1}$ Public interest organizations such as the American Civil Liberties Union (ACLU) led the litigation against the travel ban with substantial support from immigration law scholars, immigrant rights clinics, and pro bono lawyers. ${ }^{2}$ The "Me Too" movement is another widely known social justice campaign generating lawyer activ-

1. Dahlia Lithwick, The Lawyers Showed Up, SlATE (Jan. 28, 2017, 10:58 PM), https://slate.com/news-and-politics/2017/01/lawyers-take-on-donald-trumps-muslim-ban.html [https://perma.cc/EY95-VQ32].

2. See Lawsuits Related to Trump's Muslim Ban, ACLU, https://www.aclu.org/other/ lawsuits-related-trumps-muslim-ban [https://perma.cc/Z2HW-9SFD]; YLS Clinic Challenges Trump's Order Banning Refugees From Entering the U.S., Yale L. ScH. (Jan. 28, 2017), https://law.yale.edu/yls-today/news/yls-clinic-challenges-trumps-order-banning-refugees-enteringus [https://perma.cc/JN4H-J8AL]. 
ism. ${ }^{3}$ Women from all economic backgrounds are speaking up about longstanding injustices in the workplace, and their activism is leading to legal action.

In the Trump Era, we see the complexity of law. Law helps to fight injustice, but it also sanctions abuses. For example, executive privilege can both provide temporary relief from deportation to minor undocumented children and also shield corruption. ${ }^{4}$ The new progressive activism among lawyers is shedding light on an ongoing transformation of public interest law. Where public interest lawyers once primarily relied on a legal liberalist perspective to orient and justify their practices, a more inclusive strand of public interest thinking is making its way to the forefront. While law and lawyers continue to be important in defining and defending the rule of law, critical lawyers are approaching law differently than did prior generations by engaging more with communities, capitalizing on technology, and broadening their base of support to achieve sustainability.

In 1991, Professor Trubek coined the term "critical lawyers" to refer to lawyers who sought "to empower oppressed groups and individuals" and focused on forging a path to achieve "a more just society." 5 She argued that in approaching their work, critical lawyers should "encourage participation, personalize the issues, be skeptical of bureaucracy, be unbiased in approach to advocacy arenas, organize with other lawyers, and apply feminist and anti-racist analyses."6 Almost thirty years later, we resurrect the term 'critical lawyer' to describe lawyers who care about social justice and who are establishing law practices that are transforming public interest practice. ${ }^{7}$ These lawyers view themselves as central to the future of the legal profession. They regard law as just one tool for combating inequality and abuse of power. Today's critical lawyers are interested in advancing social justice by introducing new approaches to law practice. These practices represent a shift in generational thinking about how to be a progressive lawyer. We use the term 'critical lawyer' to distinguish the more traditional pub-

3. See Vicki Schultz, Yale Law Hosts Panel on the \#MeToo Movement, YALE L. REP., Summer 2018, at 35; Yale Law Journal, Stanford Law Review Publish \#MeToo Symposium, YALE L. ScH. (June 18, 2018), https://law.yale.edu/yls-today/news/yale-law-journal-stanford-law-reviewpublish-metoo-symposium [https://perma.cc/5LPS-2ZKE].

4. See, e.g., Alexa Díaz, Trump Impeachment Inquiry: A Timeline, L.A. TIMES (Oct. 24, 2019, 6:00 AM), https:/www.latimes.com/politics/story/2019-09-26/ukraine-trump-impeachmentinquiry-timeline [https://perma.cc/4HAZ-EQXS]; Tovin Lapan, A Trump Win on DACA Could Still Be a Loss for His Administration, FORTUNE (Oct. 25, 2019), https://fortune.com/2019/10/25/ daca-update-news-today-2019/ [https://perma.cc/G6JY-742N].

5. Louise G. Trubek, Critical Lawyering: Toward a New Public Interest Practice, 1 B.U. Pub. InT. L.J. 49, 50 (1991).

6. Id.

7. See Louise G. Trubek \& M. Elizabeth Kransberger, Critical Lawyers: Social Justice and the Structures of Private Practice, in CAuse Lawyering: Political Commitments And ProfessionAl ResPonsibilities 201, 201-25 (Austin Sarat \& Stuart Scheingold eds., 1998) (analyzing critical lawyers and stressing how different sites for practice can advance social change). 
lic interest law models and other social justice inspired models such as movement lawyering. ${ }^{8}$

Influenced by social entrepreneurship principles, critical lawyers are more innovative in their practices, sustaining themselves through a wider range of resources. They draw on their non-legal experiences and their communities to inspire their visions, and they seek to develop scalable models. ${ }^{9}$ Today's critical lawyers build practices that have broad coverage, flexibility, and long-term sustainability. These practices do not resemble the dominant public interest law model of past decades. They offer a more diverse, more connected, and more grassroots understanding of how law can support the quest for justice for disenfranchised populations. To democratize law practice, they engage more directly with clients and communities, encourage diversity and inclusion, and utilize a broad spectrum of resources. These new law practices are often members of networks that offer peer support for similarly situated practices across geographic boundaries. These law practices seek to build a more just society by amplifying the voices of the communities they represent.

This Article presents three examples of law practices that illustrate the differences between the old public interest approach and the emerging critical lawyer model with its new social justice mission. The first example of a critical social justice law practice is Beyond Legal Aid, formerly known as Community Activism Law Alliance. ${ }^{10}$ Beyond Legal Aid is a network of community-allied lawyers in Chicago that work with community organizations to provide needed legal services to the organizations and their constituents. Beyond Legal Aid advances a vision of community-based change through local alliances. It provides legal services to underserved communities through group activism lawyering, as opposed to direct legal services. ${ }^{11}$ Recently, a Beyond Legal Aid lawyer worked with an individual referred by the Vietnamese Association of Illinois who had been waiting years for a decision on his U.S. citizenship application. Beyond Legal Aid successfully helped the client obtain citizenship after filing a lawsuit to ensure their application was processed. ${ }^{12}$ The representation involved client self-help, advocacy by a community group, and traditional lawyering. Lam Ho, the founder of Beyond Legal Aid, views himself as a social entrepreneur. To advance his work, he accepts funding and volunteers from a broad base of support-

8. See Sameer Ashar, Movement Lawyers in the Fight for Immigrant Rights, 64 UCLA L. REV. 1464 (2017); Scott Cummings, Movement Lawyering, 2017 U. ILL. L. REV. 1645 (2017).

9. See, e.g., ASHOKA, https://www.ashoka.org/en-US [https://perma.cc/3HM9-QF54].

10. See BeYOnd LEGAL AID, www.beyondlegalaid.org [https://perma.cc/MG5V-6KVU].

11. In an in-person meeting with the author on October 18, 2019, Lam Ho explained that Community Activism Law Alliance changed its name to Beyond Legal Aid as of October 10, 2019.

12. See Accountability in the Path to Citizenship, Beyond Legal Aid (Oct. 1, 2019), https://www.beyondlegalaid.org/placeholder/accountability-in-the-path-to-citizenship [https://perma.cc/ARD9-H7S4]. 
ers. He understands that power comes from working collectively. His life experience as an Asian-American from a poverty background informs his politics and his law practice.

The second example, Law for Black Lives, is a national network of "radical lawyers and legal workers committed to building a responsive legal infrastructure for movement organizations." 13 Law for Black Lives works on a variety of issues supporting the Black Lives Matter movement, ${ }^{14}$ including policing reforms and reparations. 15 The organization stresses inclusion of the experiences of women and gender non-conforming individuals. ${ }^{16}$ Identity and community power are essential for Marbre Stalhy-Butts, the executive director of Law for Black Lives. Stalhy-Butts views lawyering as political and believes that it is important to use the law to help grassroots movements achieve their legal and political goals. ${ }^{17}$ Law for Black Lives employs technology to connect community organizations with lawyers and law school resources, such as clinics and pro bono projects. ${ }^{18}$ Through these connections, community organizations seeking social justice reforms can secure legal resources. While it currently supports itself primarily through foundation funding, the organization is exploring how to become self-sustaining through a membership model. ${ }^{19}$

A third example of public interest law transformation is TIME'S UP Legal Defense Fund, a national group that addresses sexual harassment. TIME'S UP is part of the \#MeToo movement that seeks to end sexual harassment in the workplace. ${ }^{20}$ TIME'S UP connects individuals with sexual harassment experiences to

13. About Us, LAW FOR BLACK LIVES, http://www.law4blacklives.org/about-us [https://p erma.cc/ME7V-WTCG].

14. Values, LAW FOR BLACK LIVES, http://www.law4blacklives.org/values [https://perma .cc/B33H-U9UN] ("We are working to build a stronger, more cohesive legal arm for the movement for Black Lives.").

15. Some of the work highlighted on the organization's website explains that they provide support to organizations across the country that are working to end cash bail. See Our Work, LAW FOR BLACK LIVES, http://www.law4blacklives.org/our-work [https://perma.cc/44JF-U73J].

16. Values, supra note 14 ("We are committed to the liberation and self-determination of all Black people - including Black women and LGBT/queer folks - and we are committed to implementing an intersectional, antiracist practice throughout our work.").

17. Telephone Interview with Marbre Stahly-Butts, Exec. Dir., Law for Black Lives (Feb. 18, 2019); see also Values, supra note 14 ("We're political. We understand that this moment requires political lawyering and explicit partnership with movement activists/organizers, thinking creatively and collectively about how the law can be used to support movements, and respecting activists' and organizers' political choices. We provide legal resources at the direction of community leaders and community-led, base building organizations."). 2019).

18. Telephone Interview with Erica Perry, Partnership Dir., Law for Black Lives (May 1,

19. Telephone Interview with Marbre Stahly-Butts, supra note 17.

20. This Article focuses its discussion on the TIME'S UP Legal Defense Fund. We differentiate it from the TIME'S UP movement that is part of the larger \#MeToo movement. See Megan Garber, Is This the Next Step for the \#MeToo Movement?, AtLantiC (Jan. 2, 2018), 
a network of private practitioners and pro bono lawyers who address legal issues related to sexual harassment. 21 Numerous nonprofit organizations with a history of working with women to eliminate sexual harassment collaborate with TIME'S UP to connect survivors to a network of lawyers who can provide legal and nonlegal support. ${ }^{22}$ TIME'S UP assists in identifying and funding lawyers when needed, provides media assistance, and helps gather other community resources for the clients. ${ }^{23}$ It creates alliances with labor groups, people of color, and LGBTQ clients. It also connects lawyers to "know your rights" trainings and other activities essential for their constituencies. TIME'S UP created a project to research and craft policies to combat sexual harassment and other forms of workplace discrimination. ${ }^{24}$ Its chief executive is an experienced figure who says, "we are having a global conversation around the workplaces, around the role of women and gender equity in a way in three decades I've never seen before." 25

These examples reveal a transformation of law practices engaged with social justice movements. They reflect ideas and institutions that are still developing. Their visions differ from the mainstream public interest discourse of previous generations. Each is unique and still finding its way, but we highlight three common elements. The first is their ability to integrate lawyer identity into their approach. As more lawyers enter the profession with backgrounds similar to their clients, new ideas can emerge. The second is the centrality of community and client engagement for effective legal practice. Alliances with community

https://www.theatlantic.com/entertainment/archive/2018/01/beyond-metoo-can-times-up-effectreal-change/549482/ [https://perma.cc/CS9A-V552] (discussing how Time's Up seeks to end sexual harassment in the workplace).

21. TIME'S UP Legal Defense Fund, NAT'L WoMEN's L. CTR., https://nwlc.org/times-uplegal-defense-fund/ [https://perma.cc/STJ2-CGXK].

22. We use the word "survivor" to refer to refer to individuals who experience sexual assault or harassment. An individual's experience with sexual assault or harassment varies, but in the context of this article we use the word "survivor" because it acknowledges that the individuals involved with TIME'S UP are fighting for accountability or awareness through the courts, legal processes, or through community education. For examples of nonprofit organizations collaborating with TIME'S UP see National Resources, METoo, https://metoomvmt.org/advocacy-resourceslibrary/national-resources/ [https://perma.cc/NM5Z-3UM2]; Rebecca Sun, How Time's Up Is Making an Impact Around the World, HollywoOd ReP. (June 6, 2018, 6:00 AM), https://www.hollywoodreporter.com/news/how-times-up-is-making-an-impact-around-world1117473 [https://perma.cc/29P9-2Z7J].

23. About TIME'S UP Legal Defense Fund, NAT'L WOMEN's L. CTR., https://nwlc.org/timesup-legal-defense-fund/about-times-up-legal-defense-fund/ [https://perma.cc/Q6DZ-U5GR].

24. See Hillary Lewis, Ex-Michelle Obama Chief of Staff Tina Tchen Named Time's Up CEO, HollywoOd ReP. (Oct. 7, 2019, 6:33 AM), https://www.hollywoodreporter.com/news/ michelle-obama-chief-staff-tina-tchen-named-times-up-ceo-1245808 [https://perma.cc/5PUWTTZH]; Karen Zraick, Tina Tchen, Ex-Obama Aide, Will Take Over Time's Up, N.Y. TIMES (Oct. 7, 2019), https://www.nytimes.com/2019/10/07/arts/tina-tchen-times-up.html [https://perma.cc/ W4CH-V7L5] [hereinafter Zraick, Tina Tchen].

25. See Zraick, Tina Tchen, supra note 24 . 
and client groups are essential for social justice lawyering. The third is the exploitation of all possible resources to achieve sustainability. The new practices do not eschew traditional nonprofit funders, but they also include for-profit models, campaigns for small donations, and greater use of volunteered expertise. Their innovation is based on their willingness to engage public and private resources to advance their social missions in innovative and entrepreneurial ways. TIME'S UP is particularly interesting since it is housed in the National Women's Law Center - a traditional public interest law center founded in the 1970s. ${ }^{26}$ New critical lawyer practices are giving shape not only to Beyond Legal Aid and Law for Black Lives, but are also influencing the more traditional public interest law practices. ${ }^{27}$

Their approach to social justice requires the participation of empowered communities. These lawyers work with communities by offering their technical expertise to interact with the legal system. The sustainability of these law practices relies heavily on the engagement of the community they are built to support. These law practices expand the capacity of their work by engaging networks of contributors such as donors and volunteers to help build and maintain their organizations. Critical lawyers create and engage networks through the use of technology. Their practices operate and grow through a system of nodes and networks. The practices themselves are community-powered nodes that bring more than legal expertise to the task of social justice advocacy. They use technology to grow and connect with peers across geographic distances in ways that earlier generations of lawyers and organizers were unable to do. They create or embed themselves in national and global networks that amplify the impact of their work. This nodes and networks architecture relies on peer support and multiple sources of leadership for sustainability.

This Article describes the emerging legal architecture for social justice law practice. Critical lawyers are refashioning the tools created by the public interest law and access to justice movements in order to deal more effectively with the complex challenges of social justice lawyering. These practices represent a shift in generational thinking about how to practice and influence law. We refer to these as 'critical law' practices to distinguish them from the earlier public interest law models.

Part II.A explores how legal liberalist theories influenced public interest law and describes critiques of those models. It briefly outlines the legal theories that contribute to the critical law practice perspective that challenges the traditional public interest law approaches. Part II.B reviews the environmental factors that serve as drivers for the new social justice practice architecture. The drivers are shifting law school demographics, evolving priorities for legal education, and incorporating new tools in the practice of law. Part III explores the key elements of

26. TIME'S UP Legal Defense Fund, supra note 21.

27. Interestingly, another canonical public interest organization, the ACLU, is now also adopting many aspects of critical lawyering. See infra Section III.D for a discussion of the ACLU. 
critical law practices. These elements are interest in building inclusive workplaces, integration of community and client collaboration in legal work, and financial sustainability plans that include a broad base of resources. Part III also explores the changing interests and profile of today's philanthropic contributors. Part IV explains the components of the new architecture that critical lawyers are using to build social justice law practices. We argue that the architecture links critical lawyers with communities as collaborators, and that critical lawyers use a system of nodes and networks facilitated by technology to expand their reach. The system permits scaling up regionally, nationally, and potentially globally. The Article concludes by showing how law schools and peer support groups are essential to support the architecture that these lawyers and practices need to be successful.

II.

\section{HISTORY AND DRIVERS OF THE CONTEMPORARY ENVIRONMENT}

There is an ongoing evolution in thinking about how to use law as an instrument for social change. It is led by a new generation of social justice law practitioners guided by a critique of legal liberalism, the theory behind the public interest law practice of the 1960's and 1970's. The critiques of public interest theory and practice emerged simultaneously. 28 Critical legal theory, including feminist, race, and LatCrit perspectives, informed the critiques of the public interest model. These theories called into question key tenets of the public interest 'access to justice' approach, which argued that access to law and lawyers is sufficient to ensure justice.

\section{A. The Early Public Interest Law: Legal Liberalism and its Discontents}

Legal liberalism, as we use the term, refers both to an ideology and the set of practices derived from it. At the ideological level, it is the idea that social change will occur, and a just society be achieved, as long as citizens can effectively challenge laws and have equal access to the courts. The public interest movement argued that new institutions, like nonprofit law firms engaging in lawyer-driven impact litigation and individual representation for indigent clients, were necessary to ensure full access to justice and to support constitutional challenges. ${ }^{29}$ Impact litigation firms utilize class actions or other aggregate litigation

28. Our Article primarily explores the critique from the left, but we acknowledge there is also a critique from the right that we do not discuss here. See generally David Trubek, Book Review: Balancing the Scales of Justice: Financing Public Interest Law in America, A Report by the Council for Public Interest Law, 1977 Wis. L. REV. 303 (1977). But see John P. Heinz, Anthony Paik \& Ann Southworth, Lawyers of the Right: Networks and Organization, L. \& Soc. INQUIRY 883 (2007).

29. See generally Mitchell Rogovin \& William D. Ruckelshaus, Council for Pub. Interest Law, Balancing the Scales of Justice: Financing Public InTerest Law in America 133-47 (1976) (discussing the rise of private public interest law firms and arguing that " $[\mathrm{t}] \mathrm{he}$ private public interest lawyer plays a vital role at the intersection between the ordinary marketplace for legal services and the area of wholly subsidized public interest law"). 
with similarly situated plaintiffs to challenge institutional inequalities. ${ }^{30}$ Legal services firms provide individual representation for people too poor to afford lawyers on their own. The public interest movement believed that increased access to law was essential to bring about justice. Commitment to the rule of law and efficacy of traditional legal tools were essential aspects of its ideology, despite the evidence that racism, sexism and other forms of subordination were apparent. 31

By the twenty-first century, the inadequacy of legal liberalism to deal with the complexity of social justice lawyering became increasingly apparent. Scholars such as Amna Akbar comment on the shifting ideology and practice of advancing social justice through law. Akbar describes the contrast between legal liberalist views of police reforms and the Black Lives Matter vision for addressing policing problems in Black communities. ${ }^{32}$ She discusses how the activists in the Black Lives Matter movement are skeptical about the effectiveness of legal liberalist solutions such as better training for police officers or the use of body cameras as strategies to reduce violence against Black people involved in police interactions. ${ }^{33}$ Their skepticism is rooted in an understanding of police as an instrument of law that they have experienced as oppressive. 34 Akbar compares the U.S. Department of Justice ("DOJ") proposals for dealing with police behavior in Black communities and the transformative vision of the 2016 Black Lives Matter policy platforms. ${ }^{35}$ She makes clear that the Black Lives Matter movement seeks to shift power back to people, not tweak a structure that has devalued Black lives. ${ }^{36}$ Akbar notes that social justice lawyers now focus on "redistribution of resources and shrinking of the role of the state in communities of color." 37 She contrasts this transformative vision of the Black Lives Matter movement with the conventional DOJ proposals that focus on making policy changes that continue to support the existing power structure. Despite the critique of legal liberalist advocacy, Akbar explains that the Black Lives Matter

30. One of the most significant examples of using impact litigation to challenge institutional inequalities has been in the area of school desegregation. See, e.g., Brown v. Bd. of Educ., 349 U.S. 753 (1955); Derrick A. Bell, Jr., Serving Two Masters: Integration Ideals and Client Interests in School Desegregation Litigation, 85 YALE L.J. 470 (1976).

31. See Alan D. Freeman, Race and Class: The Dilemma of Liberal Reform, 90 YALE L.J. 1880, 1887-88 (1981); Mari J. Matsuda, Looking to the Bottom: Critical Legal Studies and Reparations, 22 HARV. C.R.-C.L. L. REV. 323, 333 (1987) (discussing how "combining deep criticism of law with an aspirational vision of law is part of the experience of people of color").

32. See Amna Akbar, Toward a Radical Imagination of Law, 93 N.Y.U. L. REv. 405, 44247 (2018).

33. Id. at 407-09.

34. See id. at 421-59 (describing the history and demands of the Black Lives Matter movement and its ideology).

35. Id. at 409-11.

36. See id.

37. See id. at 447. 
movement believes that law is an important tool to fight against injustice and transform an unequal society. 38

The new practitioners we call 'critical lawyers' come from a generation of law students who are part of an enormous change in the demography of legal education. More law students now come from traditionally underrepresented backgrounds. ${ }^{39}$ Their legal education was influenced by legal liberalism, its critique, and a restructuring of the practice of law. And, they are producing new visions of social justice lawyering.

To understand the nature of the break with past ideas and practices, we need to look more closely at the underlying theory and the critique. In this part, we examine three aspects of legal liberalism: (1) the bright line between law and politics; (2) the view that a fair legal order is sufficient to ensure a just society; (3) the image of the lawyer as the hero of social justice advocacy.

\section{The Bright Line Between Law \& Politics}

Critical theorists questioned the bright line between law and politics. This line was important to early public interest lawyers who felt they had to distinguish their legal reform work from political action. The distinction served several purposes. First, it suggested that access reforms alone would be sufficient to ensure justice. Second, it suggested that lawyers, whether working on the front lines or in corporate firms, could obtain legal remedies without social unrest and street activism. And third, it was necessary because of the funding sources of much public interest practice. A key institution that emerged during this period was the Legal Services Corporation ("LSC"). The creation of the LSC embodied the belief that providing access to legal services for disadvantaged people would correct the inequities in our society. 40

However, the bright line between law and politics was not viable because lawyering is a political endeavor. ${ }^{41}$ When we divorce law from politics, we treat

38. See id. at 409 ("The movement is not attempting to operate outside of law, but rather to reimagine its possibilities within a broader attempt to reimagine the state. Law is fundamental to what movement actors are fighting against and for.").

39. See Admitted Applicants by Race/Ethnicity \& Sex, LSAC, https://www.lsac.org/dataresearch/data/admitted-applicants-raceethnicity-sex [https://perma.cc/ZJ3L-NXLX]; Law School Enrollment by Race \& Ethnicity (2018), ENJURIS, https://www.enjuris.com/students/law-schoolrace-2018.html [https://perma.cc/QN76-HTTU]; Law Schools Honored for Commitment to Increasing Diversity in Law, LSAC (July 12, 2019), https://www.lsac.org/blog/law-schools-honoredcommitment-increasing-diversity-law [https://perma.cc/GA5P-V4PJ].

40. Alan W. Houseman \& Linda E. Pearl, Ctr. For Law \& Soc. Policy, Securing Equal Justice for All: A Brief History of Civil Legal Assistance in the United States 3-5 (2007), http://legalaidresearch.org/wp-content/uploads/Securing-Equal-Justice-for-All.pdf [https://perma.cc/6BB3-BCKA] (discussing the early history of legal aid).

41. See Kimberlé Crenshaw, Critical Race Theory: The Key Writings that Formed The Movement, at xiii (Kimberlé Crenshaw, Neil Gotanda, Gary Peller \& Kendall Thomas eds., 1995) ("Scholarship - the formal production, identification, and organization of what will be called 'knowledge'-is inevitably political.'); see also Scott L. Cummings, The Social Movement Turn in 
law as inherently objective, which makes it harder to challenge. Recognizing the political nature of law "emphasizes the historical and cultural contingencies of all social arrangements, their transient, provisional, local and accidental character." 42 The political context of the time affects the selection of judges and agency administrators, and those in power influence and develop legal doctrine. ${ }^{43}$ If lawyers are not skeptical of the status quo, they perpetuate the problems that exist. ${ }^{44}$ Politics shapes our democracy, protects or devalues rights, and determines the distribution of resources. The initial draft of the U.S. Constitution did not grant women the right to vote and did not count African Americans as full citizens. Today, politically based legal inequalities are most apparent in areas such as voting rights. 45

\section{The Legal Order as Sufficient for Justice}

Legal liberalists believed that equitable administration of the rule of law can yield a just legal order, and that law and lawyers are instrumental to developing a just society. ${ }^{46}$ However, critical legal theorists question the neutrality of law and view legal order as an obstacle to justice. Many see law as a tool for those in power to preserve their position. Instead of being an instrument for justice, law can be an obstacle to democratic governance.

Feminist legal theorists claim that the law itself is one of the reasons for the continuing subordination of women. This is true despite the gains of feminist political activism. The critical feminists explore the causes of subordination by critiquing second-wave feminist theory and expanding their analyses to include race, ethnicity, class, and LGBTQ issues. As more women with working class backgrounds and women of color engaged in social justice practice, a deeper critique that recognized race, ethnicity, and class emerged. ${ }^{47}$

Critical race theorists capture an additional critique that focuses on examining power structures founded on white supremacy. 48 They embrace an intersec-

Law, 43 L. \& Soc. INQuiRY. 360 (2018). (1986).

42. See generally Robert W. Gordon, Critical Legal Studies, 10 Legal Stud. F. 335, 338

43. See id.

44. Telephone Interview with Marbre Stahly-Butts, supra note 17.

45. See, e.g., Rucho v. Common Cause, 139 S. Ct. 2484, 2506-07 (2019) (holding that partisan gerrymandering claims present inherently political questions thereby rendering them nonjusticiable).

46. See Rogovin \& Ruckelshaus, supra note 29 , at 4-5.

47. See Robin West, Women in the Legal Academy: A Brief History of Feminist Legal Theo$r y, 87$ FoRDHAM L. REV. 977, 982-94 (2018).

48. Kimberlé Crenshaw coined intersectionality as a term to address this greater topic. See Kimberlé Crenshaw, Mapping the Margins: Intersectionality, Identity Politics, and Violence Against Women of Color, 43.6 Stan. L. Rev. 1241 (1991). See also Linda S. Green, Lolita Buckner Inniss, Bridget J. Crawford, Mehrsa Baradaran, Noa Ben-Asher, I. Bennett Capers, Osamudia R. James \& Keisha Lindsay, Talking About Black Lives Matter and \#MeToo, 34 WISC. J.L., GEN. \& 
tional critique of law that argues that race, sex, class, national origin, and sexual orientation all play a role in the disenfranchisement of communities of color. 49 The critical race theory movement was instrumental in the creation of LatCrit, which promotes interdisciplinary and intersectional examinations of the Latinx experience in the U.S. ${ }^{50}$ LatCrit theorists focus on creating "scholarship through community and the creation of community through scholarship." 51 LatCrit theory explores the interface of community struggles and community building by bringing together academics and thought leaders across disciplines.

These critical theories all contribute to an understanding of the complexity of the legal order. They challenge traditional legal pedagogy that focuses on legal doctrine and does not challenge precedent that is racist, sexist, or classist. They argue that there should be more space in the classroom to discuss law's impact on marginalized communities. ${ }^{52}$

\section{Heroic Role of Lawyers}

Traditional public interest lawyering emphasizes the lawyer as the leader of change. In this model, lawyers develop strategy and emphasize legal doctrine as the driver of justice. While this approach is often effective, it does not sufficiently value the autonomy of the communities the lawyer works with. ${ }^{53}$ Scholars such as Derrick Bell, Lucie White, and Gerald Lopez criticize the traditional public interest lawyering approach that values the lawyer as essential to create more justice. ${ }^{54}$ The legal liberalist model requires a hierarchical relationship

Soc. 1, 6 n.26 (2019) ("Intersectionality is a term popularized by legal Scholar [sic] Kimberlé Crenshaw. ..").

49. Crenshaw, supra note 48; see also LiBby AdLer, GAy Priori: A QueEr CRiticAl Legal StUdies APPROACH to LAW REFORM 1-16 (2018).

50. See LATCRIT, http://www.latcrit.org/index/ [https://perma.cc/P4MK-K5N6]. LatCrit has developed annual meetings for progressive scholars who seek community in their quest for social justice. LatCrit describes the function of critical legal theory as having four basic goals. The first is to produce interdisciplinary knowledge that is critical of the status quo. The second is to promote changing transformation in society. The third is to acknowledge the links between communities that struggle in their societal subordination. Finally, the creation of community amongst scholars with those in practice who seek to inform scholarship. LatCrit's prominence has also grown with the growing number of Latinx faculty and students in law school. See Francisco Valdés, LatCrit: A Conceptual Overview, LATCRIT, http://atcrit.org/content/about/conceptual-overview/ [https://perma.cc/Z78V-CPTY].

51. Valdés, supra note 50.

52. Duncan Kennedy, Legal Education and the Reproduction of Hierarchy: A Polemic Against THE SyStem (2004).

53. See Bell, supra note 30 , at 512 (suggesting that civil rights lawyers often take action without sufficient input from their clients or the communities they claim to be helping). See generally Gerald P. Lopez, Rebellious Lawyering: One Chicano's Vision of Progressive Law Practice (1992).

54. See Bell, supra note 30; LoPEZ, supra note 53; Lucie E. White, The Transformative Potential for Clinical Legal Education, 35 OsGOODE HALL L.J. 603, 610-11 (1997). 
where the lawyer is the dominant expert. Barriers to entry into the profession and the fact that many areas of law are complex and hard for the public to understand help maintain this hierarchy. The civil rights movement provided fertile ground for the 'lawyer as hero' paradigm, and the lawyer-led nonprofit organization became the primary vehicle for public interest law practice. Public interest law practice became synonymous with working for LSC-funded nonprofit organizations or those modeled after the ACLU and the NAACP of the 1920s. ${ }^{55}$ Under the legal liberal model there were public interest lawyers, corporate lawyers, and lawyers engaged in individual representation. There was little role for lawyers who did not fit those buckets.

Critics, many with experience working with underserved communities, stress the important role of the client and communities in legal advocacy work. 56 They criticize the legal liberalist approach for overestimating the role of lawyers and underestimating the importance of identity and geography. ${ }^{57}$ Other critics question the dominance of impact advocacy and litigation through a feminist lens. ${ }^{58}$ Law students interested in social justice often find law school curriculum and career services offices focused on conventional jobs and public interest opportunities difficult to access. ${ }^{59}$ The limits of traditional public interest practice are evident.

\section{B. Drivers of the Contemporary Environment}

There are three key drivers of the current re-evaluation of legal liberalist theory and the public interest practice model: the shifting demographics in the legal profession, the evolving law school curriculum, and the incorporation of new tools in legal practice.

55. See Trubek \& Kransberger, supra note 7, at 202. According to David Cole, ACLU's national legal director, when the ACLU was initially formed in 1920, it was "an activist group fighting on behalf of workers ... and 'radicals." Initially, the ACLU filed lawsuits to demonstrate "the uselessness of the courts," but they began to make important gains through litigation. See Joel Lovell, Can the A.C.L.U. Become the N.R.A. for the Left?, N.Y. TimES MAG. (July 2, 2018), https://www.nytimes.com/2018/07/02/magazine/inside-the-aclus-war-on-trump.html [https://perma.cc/R5WS-AZJC].

56. Scholars such as Gerald Lopez, Lucie White, and Derrick Bell point out that social movements and client involvement are essential for real social and community change. See Bell, supra note 30, at 512; Jennifer Gordon, The Lawyer Is Not the Protagonist: Community Campaigns, Law, and Social Change, 95 CALIF. L. REv. 2133, 2140-41 (2007); LoPEZ, supra note 53, at 63-64; White, supra note 54, at 610-11.

57. See Bell, supra note 30, at 512; Gordon, supra note 56, at 2140-41; LOPEZ, supra note 53, at 318, 373; White, supra note 54, at 610-11; sources cited supra notes 48-49.

58. See Rebecca Sharpless, More Than One Lane Wide: Hierarchies of Helping in Progressive Legal Advocacy, 19 CliniCAL L. REV. 347 (2012).

59. See generally John Bliss, From Idealists to Hired Guns? An Empirical Analysis of "Public Interest Drift" in Law School, 51 U.C. DAVIS L. REV. 1973 (2018). 


\section{Shifting Demographics in the Legal Profession}

The increasing diversity of the American population is creating a need for lawyers who are committed to providing legal services and advocacy for unrepresented people. In the 2016 Report on the Future of Legal Services in the United States, the American Bar Association (ABA) stated that "[p]ublic trust and confidence in obtaining justice and in accessing legal services is compromised by bias, discrimination, complexity, and the lack of resources." 60 The homogenous racial composition of the legal profession surely contributes to this erosion of public trust. While a 2015 study found that $88 \%$ of lawyers are white, ${ }^{61}$ census projections estimate that by 2020 the nation's nonwhite population will approach $40 \% .{ }^{62}$

The legal profession does not reflect the demographic shifts of the last half century. Law schools, however, now have more diverse student populations than they did a decade ago. ${ }^{63}$ An ABA survey suggests small but significant increases in the number of nonwhite lawyers between 2009 and 2019. In 2016, law schools began to enroll a higher number of women in J.D. programs than men. ${ }^{64}$ In addition, more law students self-identify as LGBTQ. ${ }^{65}$ Universities have also increased their efforts to recruit more diverse law faculty. 66 A more diverse legal

60. See A.B.A., Report on the Future of Legal Services in the United States 6 (2016), https://www.americanbar.org/content/dam/aba/images/abanews/2016FLSReport_FNL_WEB.pdf [https://perma.cc/PF2R-5ZGY].

61. Id. at 31 .

62. Table 5: Race by Hispanic Origin, Data Set: 2017 National Population Projection Tables, U.S. CENSUS BUREAU, https://census.gov/data/tables/2017/demo/popproj/2017-summarytables.html [https://perma.cc/5GDB-6XTL].

63. See Jared Linzon, Law Schools Are Very Diverse, So Why Aren't Law Firms?, Fast Co. (July 30, 2018), https://www.fastcompany.com/90201095/law-schools-are-very-diverse-so-whyarent-law-firms [https://perma.cc/CU94-6YLX].

64. "In 2016, the number of women enrolled in juris doctorate programs moved past $50 \%$ for the first time. In 2017, the trend continued with women making up $51.3 \%$ of all law students. In 2018 , the data once again revealed that more women were enrolled in law school than men. Specifically, females made up $52.39 \%$ of all students in ABA-approved law schools." Where Do Women Go to Law School? Here Are the 2018 Numbers, A.B.A. FOR LAw StUdents: Before the BaR (Feb. 28, 2019), https://abaforlawstudents.com/2019/02/28/where-do-women-go-to-law-school2018-numbers/ [https://perma.cc/Y4DW-TS37].

65. See LGBTQ \& Law School, LSAC, https://www.lsac.org/discover-law/diversity-lawschool/lgbtq-law-school [https://perma.cc/JA3E-TWH6].

66. Data on law school faculty hiring is collected annually by the American Association of Law Schools (AALS) since most law school tenure-track faculty hiring is conducted through AALS's annual conference. The AALS published demographic data on U.S. law professors until 2009 but removed it all in 2014. See Meera E. Deo, Unequal Profession: Race and Gender in Legal ACADEmia 4 and n.2 (2019); see also Jim Lindgren, Law Faculty Diversity: Successes and Failures, WASH. Post (Mar. 21, 2015, 8:12 AM), https://www.washingtonpost.com/news/volokhconspiracy/wp/2015/03/21/law-faculty-diversity-successes-and-failures/ [https://perma.cc/8S8D$\mathrm{CBHK}$ ] (discussing the findings of a study showing that diversity hiring in law schools has been a great success for women and traditionally underrepresented ethnicities); LSU Law Named One of 
academy is more vigilant about the importance of identifying and reaching out to previously excluded students, including students from different socioeconomic backgrounds. ${ }^{67}$

\section{Evolving Legal Education}

Law school curriculum is crucial in fostering students' visions of what lawyers can do. Course offerings allow or inhibit students pursuit of their social justice ambitions. ${ }^{68}$ The increasing diversity in legal education influences what law schools teach. Creating an inclusive legal profession requires expanding curricula to involve other disciplines and practical skills. Most law schools today have a number of courses and experiences that introduce students to working with lowincome communities and expose them to social justice ideals.

Of the 203 law schools accredited by the ABA, only twenty-eight do not report some type of pro bono or public interest program. ${ }^{69}$ A Center for the Study of Applied Legal Education survey of 187 law schools reported 1,433 clinical offerings in 2016-17.70 Pro bono experiences and clinics offer students real life exposure to the limits of law. Through these experiences, students see entrenched inequalities despite years of legal prohibitions against many forms of discrimination. They advocate in courts that lack resources, and they experience the frustration of being unable to address their clients' root problems. ${ }^{71}$

The more diverse law schools are crucial to critical lawyers. Lam Ho, founder of Beyond Legal Aid, emphasizes that many young lawyers develop their professional identities in law school. He argues that new curricula helps law students develop greater social consciousness. Ho notes that he studied articles about social justice legal practice that criticized liberal legalism, and that his law

the Best Law Schools for Black Students by Lawyers of Color, LSU LAw (May 13, 2019), https://www.law.lsu.edu/news/2019/05/13/lsu-law-named-one-of-the-best-law-schools-for-blackstudents-by-lawyers-of-color/ [https://perma.cc/ZEF3-4Q7W] (stating that LSU Law was named one of the best law schools for black students due to the increased mentoring and training of prospective law professors and administrators and the number of black faculty).

67. See Meera E. Deo, Faculty Insights on Educational Diversity, 83 Fordham L. Rev. 3115, 3144-45 (2015); see also Meera E. Deo, The Ugly Truth About Legal Academia, 80 BROOK. L. REV. 943, 989-93 (2015).

68. See John Bliss, Drifting Law Students, 4 The Practice (2018).

69. See Public Interest Clinics, A.B.A., https://www.americanbar.org/groups/center-probono/resources/directory_of_law_school_public_interest_pro_bono_programs/definitions/pi_pi clinics/ [https://perma.cc/Q6-66-9JFX].

70. See Robert R. Kuehn \& David A. Santacroce, Ctr. for Study Applied Legal Educ., The 2016-2017 Survey of Applied Legal EduCATion 1, 13 (2017), https://uploadsssl.webflow.com/5d8cde48c96867b8ea8c6720/5da859d8ad42af693e72957d_Report_on_201617_CSALE_Survey.pdf [https://perma.cc/9N9J-R6LX].

71. See generally Rebecca Sandefur \& Jeffrey Selbin, The Clinic Effect, 16 CLINICAL L. REV. 57 (2009) (discussing the experience of law students in clinic and the potential effects of clinic participation on public service employment). 
school education influenced his vision for Beyond Legal Aid. ${ }^{72}$ Marbre StahlyButts remembers her law school experiences similarly. She points to her engagement in clinical and pro bono work as the most relevant parts of her legal education, as they connected with her identity and life experiences.

Lawyers interested in advancing social change often grapple with the complexity of law. The contradictions of the legal system become apparent to lawyers through their legal education and their personal experiences. Those that emerge as critical lawyers still believe in law as a tool but equally value the experience of clients and communities in their quest to democratize law. ${ }^{73}$

\section{Incorporating New Tools in Legal Practice}

Despite the legal profession's ties to tradition, lawyers and legal institutions have restructured in a number of ways. The most significant changes for lawyers committed to social justice in the last few decades are the growth of pro bono programs, the introduction of technology to facilitate legal information services, and the rise of multidimensional practices.

Organized pro bono programs became a key driver in changing the legal profession in the 1990s. ${ }^{74}$ As practice restrictions increased and funding decreased for LSC-funded legal aid organizations, large corporate law firms stepped in to provide more free legal services. In the early 1980s, the LSC began to require legal aid grantees to devote $12.5 \%$ of their grants to engage the private bar. ${ }^{75}$ Instead of hiring more legal aid attorneys, most grantees used that funding to hire staff to coordinate pro bono services from the private bar. ${ }^{76}$ The dedication of federal funds to incorporate private lawyers in legal service delivery to the poor coincided with the growth of the corporate law sector. That combination produced a pro bono culture that has become its own institution.

The availability of pro bono work has significantly changed the way lawyers engage with the provision of free legal services for the poor. Lawyers who want to contribute to the advancement of social justice but who work in the corporate sector often engage in limited pro bono work. ${ }^{77}$ Political ideology and personal

72. E-mail from Lam Ho, Exec. Dir. \& Founder, Beyond Legal Aid, to Louise Trubek, Clinical Professor of Law Emerita, Univ. of Wis. Law Sch. (Feb. 24, 2020, 12:10 EST) (on file with author) [hereinafter E-mail from Lam Ho].

73. See generally Trubek \& Kransberger, supra note 7.

74. See The Rights Revolution, Revisited: Institutional Perspectives on the Private ENForCEMENT OF Civil Rights In the U.S. 281 (Lynda G. Dodd ed., 2018).

75. See Luz E. Herrera, Rethinking Private Attorney Involvement through a Low Bono Lens, 43 LoY. L.A. L. REV. 1, 26-27 (2009).

76. See id. at 7 n.26.

77. See Deborah L. Rhode, Pro Bono in Principle and in Practice, 53 J. Legal Edu. 413, 453 (2003). See generally Steven A. Boutcher, Growth of Large Law Firm Pro Bono Programs, in Beyond Elite Law: Access to Civil Justice in America 270 (Samuel Estreicher \& Joy Radice eds., 2016) (discussing the growth of the pro bono culture in corporate law firms). 
experience may drive some of these lawyers to pro bono. It may be particularly difficult for lawyers who have the responsibility of being the primary breadwinners or who do not have a family, partner, or other source of subsidy to do social justice work full-time. Pro bono work allows corporate attorneys to contribute to advancing access to the law and possibly to justice. The availability of pro bono opportunities also creates a pool of attorneys available as a resource to critical law practices. 78

Another significant development in the practice of law is the introduction of technology to facilitate legal information and services. Court administrators overwhelmed with the number of self-represented litigants struggling to understand laws and legal procedure engaged technology to address the great need for legal information and assistance. Document automation that permits individuals to fill out forms has facilitated a self-help culture in state courts around the country. ${ }^{79}$ Form automation and limited scope representation have allowed legal services consumers and lawyers to form more collaborative relationships. ${ }^{80}$ Online legal services are now common. Court self-help programs, private sector legal services products such as LegalZoom, and even apps for courts and organizations developed by law school clinics are now the norm. ${ }^{81}$ The delivery of legal services today often involves attorneys and consumers each doing some of the work. ${ }^{82}$ These new technologies offer tools to confront the geographic isolation from legal services in rural and urban underserved communities. 83

Another development is the rise of multidimensional practice. ${ }^{84}$ The lines between litigation, lobbying, and individual representation are no longer rigid. ${ }^{85}$ We now see the blurring of once sharp distinctions between individual represen-

78. But see Atinuke O. Adediran, Solving the Pro Bono Mismatch, U. Colo. L. REv. (forthcoming 2020) (discussing the difficulties of matching social justice practices with appropriate pro bono attorneys).

79. For example, most states have websites that provide legal services consumers with information and forms to help address common legal issues related to housing, family law, and small claims. State and federal government agencies have also invited in technology to facilitate legal forms and information. E.g., TEXASLAwHELP.ORG, https://texaslawhelp.org/ [https://perma.cc/EK2H-QGTW].

80. See Rhode, supra note 77 , at 445 .

81. In addition, the private sector has built multiple business models that allow consumers to access legal document for nominal fees. See, e.g., LEGALZoOM, https://www.legalzoom.com [https://perma.cc/WE4Q-Y3T3].

82. See Mark A. Cohen, Clients Need Legal Services But Not Necessarily Lawyers, ForBES (Feb. 19, 2019, 7:35 AM), https://www.forbes.com/sites/markcohen1/2019/02/19/clients-needlegal-services-but-not-necessarily-lawyers/\#14a995b5702d [https://perma.cc/C9Z6-KT89].

83. See Lisa R. Pruitt, Amanda L. Kool, Lauren Suedall, Michele Statz, Danielle M. Conway \& Hannah Haksgaard, Legal Deserts: Multi-State Perspective on Rural Access to Justice, 13 HARV. L. \& POL'y 15, 72-73 (2018) [hereinafter Legal Deserts].

84. See generally Alan K. Chen \& Scott Cummings, Public Interest Lawyering: A CONTEMPORARY APPROACH 515-24 (2014).

85. Id. 
tation and policy developments, litigation and community activism, and research and activism. There has also been an increasing role for community economic development and transactional legal work to help underserved communities build infrastructure. 86

One important aspect of multidimensional practice is collaboration with social scientists. When lawyers engaged social science to desegregate public schools in Brown v. Board of Education, the use of empirical research to advance social justice was novel. Engaging in empirical research is essential to social justice law practice today. Practitioners can use the tools of social science research to evaluate the effectiveness of various advocacy approaches. An example is how studies of legal deserts have led legal services providers to become more aware of the geographic reach of their practices. ${ }^{87}$ TIME'S UP's recent decision to start an Impact Lab highlights the importance of social science research. This new project focuses on research and policy development on sexual harassment. ${ }^{88}$ There are groups of social scientists and law faculty that are initiating efforts to develop the expertise and tools to evaluate social justice law practices. ${ }^{89}$ The Bellow Scholars program, initiated by the Clinical Legal Education Section of the AALS, is one such effort. 90 It builds a community for clinicians who are interested in evaluating the effectiveness of social justice law projects on the problems they engage with in practice. A frequent collaborator of that group is Rebecca Sandefur, who is working with the American Bar Foundation to create a new field of study focusing on evaluating efforts that contribute to the effective use of law. 91

86. See Susan R. Jones, Current Issues in the Changing Roles and Practices of Community Economic Development Lawyers, 2002 WIS. L. REV. 437, 3-9 (2002).

87. See Legal Deserts, supra note 83, at 33.

88. See Zraick, Tina Tchen, supra note 24.

89. One important organization to note is the Law \& Society Association, founded in 1964 to "consider law in the context of broad social theories." History of the Law and Society Association, L. \& SoC'Y Ass'N, https://www.lawandsociety.org/history.html [https://perma.cc/W2NG-STUT].

90. See The Bellow Scholar Program, https://sites.google.com/view/bellowscholars /home [https://perma.cc/HJC7-CSX5].

91. Professor Rebecca Sandefur is a leading scholar on access to justice and founded the American Bar Foundation's Access to Justice initiative. See Rebecca Sandefur, Access to Justice, AM. BAR. FounD., http://www.americanbarfoundation.org/research/project/106 [https://perma.cc /9JTF-XVKS]. Her work includes empirical studies and reports on access to civil justice. See id. Jim Greiner, Harvard Law School professor and faculty director of the A2J Lab, is another important contributor. A2J Lab creates trials to evaluate efforts to address the delivery of legal services. Greiner's empirical research has challenged the belief that legal services can only be improved by making lawyers more accessible. See D. James Greiner \& Cassandra Wolos Pattanayak, Randomized Evaluation in Legal Assistance: What Difference Does Representation (Offer and Actual Use) Make?, 121 YALE L.J. 2118 (2012) (describing a randomized control trial demonstrating that representation by a legal services provider did not have a statistically significant effect on the plaintiff getting a favorable decision in an unemployment benefits case). 
III.

\section{DEMOCRATIZING SOCIAL Justice LAW PRACTICE}

New social justice practices today use law as one of many tools to advance a progressive agenda. Law is no longer as central for social reform as it was for earlier public interest lawyers. Today's critical law practices seek to democratize law by engaging more people and resources in their work. The law practices and networks we discuss in the introduction range from a newly formed, community oriented nonprofit 501(c)(3), to a historic public interest law firm that now relies on pro bono lawyers, to a national network of lawyers, community organizations, and law school clinics that link social movements with legal resources. The examples share characteristics that are indicative of how social justice practices are exploiting current resources as well as responding to the limits of previous practices. The chart below summarizes some of the key differences between the new social justice law practices and more traditional public interest law approaches.

\begin{tabular}{|l|l|l|}
\hline $\begin{array}{l}\text { Relation between Law } \\
\text { \& Justice }\end{array}$ & $\begin{array}{l}\text { Public Interest Law } \\
\text { will ensure social justice }\end{array}$ & $\begin{array}{l}\text { Critical Law Practices } \\
\text { problem as well as the so- } \\
\text { lution }\end{array}$ \\
\hline Intellectual origins & Legal Liberalism & $\begin{array}{l}\text { Critical Lawyering } \\
\text { Rebellious Lawyering } \\
\text { Movement Lawyering } \\
\text { Community Lawyering }\end{array}$ \\
\hline Role of Lawyers & $\begin{array}{l}\text { Ensure access to justice } \\
\text { through direct legal ser- } \\
\text { vices and policy advoca- } \\
\text { cy; enforce Constitution }\end{array}$ & $\begin{array}{l}\text { Develop legal political } \\
\text { strategies jointly with af- } \\
\text { fected communities }\end{array}$ \\
\hline Nature of practice & $\begin{array}{l}\text { Free standing, lawyer- } \\
\text { led nonprofit firms }\end{array}$ & $\begin{array}{l}\text { Multiple models includ- } \\
\text { ing for-profit, lawyers } \\
\text { embedded in community } \\
\text { groups, partnership with } \\
\text { pro bono programs }\end{array}$ \\
\hline Lawyering activities & $\begin{array}{l}\text { Litigation, lobbying, } \\
\text { administrative hearings }\end{array}$ & $\begin{array}{l}\text { The same, but also multi- } \\
\text { dimensional practice, } \\
\text { community activism, } \\
\text { marketing, client en- } \\
\text { gagement and self-help }\end{array}$ \\
\hline Support base & $\begin{array}{l}\text { Foundation and govern- } \\
\text { ment grants, court- } \\
\text { awarded fees }\end{array}$ & $\begin{array}{l}\text { The same, but also small } \\
\text { donor online funding, } \\
\text { shared revenue with } \\
\text { NGOs, and fees from cli- }\end{array}$ \\
\hline
\end{tabular}




\begin{tabular}{|l|l|l|}
\hline & & ents \\
\hline Personnel & Elite, white, male & $\begin{array}{l}\text { Also women, minorities, } \\
\text { LBGTQ, working class } \\
\text { origin }\end{array}$ \\
\hline
\end{tabular}

The next sections expand on the significant elements of the organizational structures of these practices. Critical lawyers create organizations that prefigure the equality for which they advocate by creating inclusive workplaces. Instead of bowing to rigid professionalism, they blend their identities with their work to create new professional norms. Critical lawyers aim to collaborate with clients and communities to articulate a vision that avoids hierarchies. Their strategic plans use local and innovative resources to achieve sustainability so they are not dependent on a single source such as the government, foundations, or law schools. They embrace creative and innovative approaches to sustainability and engage a variety of partnerships. These approaches include a more participatory donor base comprised of small monetary on-line contributions, volunteer hours including pro bono legal expertise, fees from clients, and sharing fees with nonprofit collaborators.

\section{A. Inclusive Workplaces \& Lawyer Identity}

The legal profession today is more diverse than it ever has been-in terms of race, ethnicity, gender, sexual orientation, and socioeconomic class. ${ }^{92}$ Many entrants to the profession struggle with how to merge their commitments to their communities and the role of a lawyer. ${ }^{93}$ A lawyer's identity is integral to their approach to their professional role. While 'bleached-out professionalism,' which subordinates personal identity to professional identity, is the dominant model of professional development, today's critical lawyers insist on integrating their own identity and commitments with their roles. This has been noted in the struggles of women, racial, and ethnic groups in the legal profession. 94

It is crucial for students, and new lawyers, to understand the importance of workplaces in the integration of their lawyer role with that of their racial, gender, and political commitments. Workplaces are crucial elements in achieving successful identities as lawyers and living meaningful lives. A workplace can be

92. Inst. for InClusion in Legal Profession, IILP Review 2019-2020: The State of Diversity AND INCLUSION IN THE Legal Profession 13-25 (2019), http://www.theiilp.com /resources/Documents/IILP_2019_FINAL_web.pdf [https://perma.cc/MRT9-MRGH].

93. See, e.g., Cecilia L. Ridgeway, Framed By Gender: How Gender Inequality PERSISTS IN THE MODERN WORLD 195-96 (2011) (discussing how professional socialization affects gender parity); Sanford Levinson, Identifying the Jewish Lawyer: Reflections on the Construction of the Professional Identity, 14 CARDOzO L. REV. 1577 (1992) (exploring how Jewish identity in the legal profession is defined or experienced through professional identity); David Wilkins, Identity and Roles: Race, Recognition, and Professional Responsibility, 57 MD. L. REv. 1502 (1998) (discussing the identity and ethical obligations of Black lawyers).

94. See sources cited supra note 93. 
discriminatory regardless of the demographics of its employees. ${ }^{95}$ It can also be implicitly racist and sexist if its practices ignore the identity of its employees. 96 A commitment to a safe and harassment-free workplace leads to an examination of how conventional legal doctrine encourages implicit harassment. 97 For example, there is currently a rethinking of the legal standards for challenging sexual harassment in the workplace. ${ }^{98}$ Employment law scholars are sharing ideas about how to more effectively argue sexual harassment cases. 99

All the examples discussed in this article strive to create workplaces that allow for the construction of a meaningful career in law. Inclusive workplaces can enable a lawyer to figure out a route to achieve their goals. This often feeds back into the development of innovative workplaces. The Harvard Law School newsletter, The Practice, analyzes the law school experience and reports on studies of the construction of law students' professional identity while in law school. One researcher found that "students who pursued jobs in the public-interest sector tended to sustain a more proximate conception of professional identity, overlapping with racial, gender, political and ... other roles."100 His study documents how law students understand the tension between "thinking like a lawyer" and the possibility of a career as a well-respected and effective lawyer for disadvantaged people. 101

Most social justice lawyers, in figuring out how and where they should practice, are aware of integrating their identity into their practice. This is crucial to their sense of self and ability to pursue a meaningful career. Developing lawyers both responsive to underrepresented groups and comfortable in their lawyer identity is a major task. Critical lawyers define a successful career as one where they can be true to their identities and command respect for their legal knowledge. Lam Ho at Beyond Legal Aid, Marbre Stahly-Butts at Law for Black

95. See, e.g., Joyce S. Sterling \& Nancy Reichman, Overlooked and Undervalued: Women in Private Law Practice, 12 ANN. ReV. L. \& Soc. SCI. 373, 384-85 (2016).

96. See generally Roberta D. Liebenberg \& Stephanie A. Scharf, A.B.A., Walking Out The Door: The Facts, Figures, and Future of Experienced Women in Private Practice (2019), https://www.americanbar.org/content/dam/aba/administrative/women/walking-out-thedoor-4920053.pdf [https://perma.cc/8PC2-BV4Q]. 2017).

97. See Robin West, The New Legal Criticism, 177 Colum. L. Rev. OnLINE 144, 162 (June 6,

98. See, e.g., R. Shep Melnick, New Title IX Rules Require Hearings, Cross-Examinations in Colleges but Not High Schools, EDUCATIONNEXT (Jan. 16, 2019), https://www.educationnext.org /new-title-ix-rules-require-hearings-cross-examinations-in-colleges-not-high-schools/ [https://perma.cc/3MP7-YYWL].

99. See, e.g., L. Camille Hebert, Is 'MeToo' Only a Social Movement or a Legal Movement Too? 14 (Emp. Rights \& Emp'y Pol'y J., Ohio State Pub. L. Working Paper No. 453, 2018), https://ssrn.com/abstract=3236309; Yale Law Journal-Stanford Law Review Publish \#MeToo Symposium, supra note 3.

100. John Bliss, Divided Selves: Professional Role Distancing Among Law Students and New Lawyers in a Period of Market Crisis, 42 L. \& SOC. INQUIRY 855, 855 (2017).

101. See id. at $867-68$. 
Lives, and Tina Tchen at TIME'S UP Legal Defense Fund all offer a critical view of the law and legal doctrine and at the same time are committed to the aspirational potential of law. 102

Finally, critical lawyering can enable clients to realize and maintain their own identities. Lawyers assist by fighting against all types of discrimination, advocating for harassment-free workplaces, and representing tenants facing eviction. ${ }^{103}$ This advocacy enables clients to maintain families and achieve economic security. All the examples highlighted are committed to using legal work to help their clients achieve stability. The ability of critical lawyers to integrate their own identity in their work allows them to develop and pursue strategies, alongside clients, that are more organic and effective for the communities they represent.

\section{B. Community \& Client Collaborations}

Critical lawyers today aim to collaborate with clients and communities. Collaborations permit clients and communities to articulate their priorities that often reflect their cultural and ideological preferences. Critical lawyers view the engagement with clients, communities and other stakeholders, including non-legal professionals, as instrumental for seeking justice. Tackling problems through multiple perspectives is a core part of critical lawyering. ${ }^{104}$ Moreover, collaboration taps into a broader vision of how to combat inequality and bias, as it can flatten the hierarchical structure of law firms, creating what scholars refer to as horizontal practice. 105 This approach tends to blur distinctions such as civil versus criminal, anti-poverty versus environmental, and work versus personal. The development of collaborations across traditional divides allows new alliances to develop for greater effectiveness.

Law for Black Lives' National Bail Out project is an example of a community collaboration. ${ }^{106}$ National Bail Out is an organizing effort to bring attention to the pre-trial detention system's disproportionate impact on poor people and

102. See West, supra note 47, at 987-94 (describing feminist legal theorists' aspirations to reform law and legalism to promote gender equality).

103. See Matthew Desmond, Evicted: Poverty and Profit in the American City 304 $05(2016)$. (2019).

104. Rebecca L. Sandefur, Access to What?, 148 Daedelus J. ACAD. Arts \& SCI. 49, 53-54

105. See Sameer M. Ashar \& Meena Jagannath, Case Study 1: Movement Groups with Flat, Innovative Governance Structures, 47 HofSTRA L. REV. 19, 19 (2018); Michael Haber, The New Activist Non-Profits: Four Models Breaking from the Non-Profit Industrial Complex, 73 U. MiAmI L. REV. 863, 916 (2019).

106. See Black Mama's Day Bailout, LAw FOR BLACK Lives, http://www.law4black lives.org/blackmamasbailout [https://perma.cc/WE7E-USYA] [hereinafter Black Mama's Day Bailout]; see also Brandee Sanders, \#FreeBlackMamas Initiative Aims To Bail Out Over 100 Black Moms For Mother's Day, NewsOne (May 11, 2019), https://newsone.com/3852487/free-blackmamas-initiative-bails-out-black-moms-for-mothers-day/ [https://perma.cc/Z8P8-6NDJ]. 
poor communities. 107 Community organizations working with Law for Black Lives seek reforms in both civil and criminal arenas as ways to challenge the current legal system. 108 They want more money spent on community development rather than on criminalization. ${ }^{109}$ By attacking both civil and criminal legal barriers, Law for Black Lives is able to collaborate with a wider variety of legal clinics and other organizations than conventional criminal law reform groups. ${ }^{110}$ Law for Black Lives also backs environmental justice campaigns. ${ }^{111}$ It partners with law school clinics to help communities set up community land trusts, which in turn foster ecological initiatives and improve economic conditions. 112

Critical lawyers also collaborate with labor unions and other worker organizations. Unions often use collective bargaining contract language developed with women's groups to improve conditions for women at the workplace. TIME'S UP, for example, is collaborating with the labor group Fight for \$15 to fight harassment at McDonald's. ${ }^{113}$ Beyond Legal Aid works with unions. The organization itself is now unionized. Lam Ho sees lawyers, workers, and organizers as able to work together. ${ }^{114}$ In his view, the Beyond Legal Aid model can support workers to build their own power and confront their bosses. One of its projects protests sexual harassment at restaurants in Chicago in collaboration with unions and other social justice groups.

TIME'S UP is developing relationships with community organizations that have experience working against sexual harassment. This community-based approach helps TIME'S UP respond to the critique that the U.S. women's rights movement is not inclusive of women of color or sensitive to the needs of lowerincome women. ${ }^{115}$ By linking community organizations with attorneys, TIME'S

107. See Black Mama's Day Bailout, supra note 106.

108. Telephone Interview with Marbre Stahly-Butts, supra note 17.

109. Id.

110. Id.

111. Movement Partners, LAw FOR BLACK LIVES, http://www.law4blacklives.org/movementpartners [https://perma.cc/L75C-VB5H].

112. See Clinical Cohort, LAW FOR BLACK Lives, http://www.law4blacklives.org/new-page1 [https://perma.cc/858V-3M9G].

113. See David Yaffe-Bellany, McDonald's Lawsuit Targets Pervasive Culture of Sexual Harassment, N.Y. Times (Nov. 12, 2019), https://www.nytimes.com/2019/11/12/business/mc donalds-harassment-lawsuit.html [https://perma.cc/LD7P-9QW4].

114. Telephone Interview with Lam Ho, Exec. Dir. \& Founder, Beyond Legal Aid (Feb. 14, 2019) [hereinafter Beyond Legal Aid].

115. See, e.g., Melissa Murray, The Making of Black Lives Matter - and Making it More Inclusive, WASH. POST (Oct. 4, 2018, 11:46 AM), https://www.washingtonpost.com/outlook/themaking-of-black-lives-matter - and-making-it-more-inclusive/2018/10/04/2b3e1ef6-bb86-11e8bdc0-90f81cc58c5d_story.html?noredirect $=$ on\&utm_term $=.8 \mathrm{a} 2 \mathrm{ad} 38 \mathrm{~b} 3649$

[https://perma.cc/5UDP-WL4B] (acknowledging that even those within the civil rights movement marginalized vulnerable groups, including women of color, and recognizing that multiple systems of oppression may intersect to further marginalize these groups). 
UP is able to expand the reach of its efforts to impact less affluent women and women of color. Additionally, TIME'S UP's outreach grants fund NGOs that support women's advancement. These NGOs engage previously excluded populations and connect them to attorneys that provide legal assistance. The attorneys also offer 'know your rights' information and other educational assistance that help a greater array of women enforce their rights. The grantees, who receive an average of $\$ 750,000$ from TIME'S UP, have experience and links to the lowwage, disability, immigrant, and LGBTQ communities. TIME'S UP looks to distribute its grants to NGOs that have community ties, outreach potential, and a demonstrated commitment to advocacy for workers' rights. ${ }^{116}$ The grantees are geographically distributed and diverse. They range from National Interfaith Worker Justice to the Latino Community Fund in Georgia to the Chicago-based Healing to Action. The selected projects use worker-led meetings, videos, apps, virtual meetings, and social media to share best practices and lessons learned.

Social justice law practices seek community integration. These communities may be based on geography, such as Beyond Legal Aid in Chicago, identity, such as TIME'S UP, or ideology, such as Law for Black Lives. These practices view the community and individual clients as integrated into their advocacy and education projects, and the practices are in turn integrated into the communities. Through their advocacy, lawyers encourage local programs and small business by providing legal support for economic development programs. ${ }^{117}$ Many of the social justice law firms assist local entrepreneurs in their neighborhoods. ${ }^{118}$ For example, using legal tools to assist nonprofits that support poetry and music venues is on the rise. At a recent event sponsored by a women's legal organization, speakers from all types of cultural and business organizations spoke. 119 Participants expressed their appreciation for the crucial role of the legal organization in providing them support and legitimacy as they pursued their interests.

Some organizations engage in even more unconventional cultural collaborations. The ACLU works with actor and standup comedian Sasheer Zamata to expand the reach of ACLU's Women's Rights Project.120 ACLU attorneys meet annually with Zamata to brief her on cases and provide her with data that she can

116. Telephone Interview with Saru Jayaraman, President \& Founder, Rest. Opportunities Ctrs. United (ROC United) (Feb. 19, 2019).

117. See generally Susan R. Jones, Supporting Urban Entrepreneurs: Law, Policy, and the Role of Lawyers in Small Business Development, 30 W. New ENG. L. REv. 71 (2007); Amanda M. Spratley, Connecting Law and Creativity: The Law of Lawyers in Supporting Creative and Innovative Community Development, 8 Hastings Bus. L.J. 221 (2012).

118. Telephone Interview with Lam Ho, Exec. Dir. \& Founder, Beyond Legal Aid (May 31, 2018) [hereinafter Beyond Legal Aid 2].

119. See The Future is Now, Conn. Women's Educ. \& Legal Fund, www.cwealf.org/advancement-leadership/the-future-is-now/ [https://perma.cc/Y622-XNZG].

120. Alexis Soloski, Sasheer Zamata Finds Humor at the A.C.L.U., N.Y. TIMES (Oct. 4, 2019), https://www.nytimes.com/2019/10/04/style/sasheer-zamata-snl-aclu.html [https://perma.cc/W9E2-3S36]. 
use in her act. In addition to her standup material, Zamata has written an essay and recorded a video integrating Women's Rights Project themes. Entertainers and other public figures have access to audiences that many lawyers do not. By working with entertainers and other public figures, lawyers advocating for social justice can expand their message to new audiences. These types of collaborations have existed for many years in other sectors, but they are beginning to have an impact in the legal profession. ${ }^{121}$

Social justice lawyers collaborate with clients. Critical lawyering's emphasis on community and client engagement has helped drive the growing interest in alternative forms of representation, including unbundled legal services. ${ }^{122}$ Full representation is costly, and lawyers are not always readily available. However, unbundled legal services allow consumers to do some of the legal work themselves, leaving only the most legal-knowledge-intensive tasks to lawyers. This approach keeps costs low and allows consumers to retain more autonomy over their cases. Unbundled legal services take many forms. Some consumers turn to advice clinics located in the community or online. ${ }^{123}$ Some turn to a trusted community resource who has connections with lawyers. By working with religious leaders, social service providers, educators, and other community leaders, lawyers can be more effective in reaching legal services consumers.

Beyond Legal Aid's Lam Ho offers an example of effective community collaboration. He worked in legal aid organizations for six years and believes his advocacy for individuals did not translate into greater equality or social justice in the communities where he worked. ${ }^{124} \mathrm{He}$ envisioned a way that social justice legal work could be community directed. He founded Beyond Legal Aid with three goals in mind: embed lawyers in the geographic communities they serve, let the client into the legal work, and participate in social movements. He views the new model as community activism lawyering. Beyond Legal Aid collabo-

121. For more examples, see Michael Goldberg, Live Aid 1985: The Day the World Rocked, Rolling STONE (Aug. 16, 1985, 1:45 AM), https://www.rollingstone.com/music/music-news/liveaid-1985-the-day-the-world-rocked-180152/ [https://perma.cc/C439-LYJQ] (describing how over sixty pop stars performed at Live Aid, a concert that raised $\$ 40$ million for starving people in drought-stricken Africa); Jillian Steinhauer, A Show of Artists Galvanized by the Abortion Debate, N.Y. Times (Jan. 23, 2020), https://www.nytimes.com/2020/01/23/arts/design/abortion-arsenalcontemporary.html [https://perma.cc/PMS8-8MXU] (discussing how more than sixty artists contributed to an "emergency exhibition" where all proceeds went to political fundraising groups focused on reproductive rights); Christopher Zoukis, John Legend Fights for Criminal Justice Reform, PRISON LEGAL News (July 2, 2018), https://www.prisonlegalnews.org/news/2018/jul/2/johnlegend-fights-criminal-justice-reform/ [https://perma.cc/75DQ-VXXF] (detailing John Legend's fight for criminal justice reform by launching the Unlocked Futures initiative to fund formerlyincarcerated entrepreneurs).

122. See generally Unbundling Resource Center, A.B.A., https://www.americanbar.org/ groups/delivery_legal_services/resources/ [https://perma.cc/UQ7C-ZREW] (describing the concept of unbundled legal services).

123. See Sandefur, supra note 104 , at 50-52.

124. Beyond Legal Aid, supra note 114. 
rates with activists and seeks to create greater empowerment. Beyond Legal Aid provides legal services to community groups that are committed to improving the lives of low-income people. The integration of social movements with legal protections and advocacy strengthens the ability of the clients to express their identities. Social justice lawyering moves away from the lawyer as the central protagonist to the lawyer as collaborator with the client and community.

\section{Sustainability through Social Entrepreneurship}

The ideas and practices of social entrepreneurship are influencing how lawyers think about law practice. 125 Developing sustainable business models for social justice practice has always been a conundrum. Traditional public interest practices adopt the tax-exempt nonprofit model, which relies on charitable contributions or government funding and largely eliminates fees from clients. ${ }^{126}$ The practices discussed in this article are looking at entrepreneurial models as they envision how to scale and sustain their practices.

In the past decades, an expanded range of practice structures for social impact legal work has emerged. We have seen a rise in hybrid models where nonprofits also accept fees from clients and where pro bono lawyers from corporate firms have become a crucial element in poverty law practice. The social entrepreneurship bug has also bitten lawyers. ${ }^{127}$ New organizational forms such as benefit corporations and social entrepreneurship organizations like Ashoka are encouraging lawyers to challenge traditional law practice models by blurring the distinction between nonprofit and for-profit ventures. ${ }^{128}$ Mixed business models that allow lawyers to 'do good while doing well' are key to the continued development of social justice law practices. For example, Lam Ho at Beyond Legal Aid envisions a more revenue-based model for his organization. He has a fiveyear plan for sustainability and scalability that includes expansion in Chicago and perhaps nationally. ${ }^{129}$ Beyond Legal Aid is also exploring collaborations with NGOs to provide legal services as part of the NGOs' programs. The NGOs would apply for grants to subsidize costs of legal services provided by Beyond Legal Aid to the NGOs' constituents.

125. The Institute for Social Entrepreneurs describes social entrepreneurship as " $[\mathrm{t}] \mathrm{he}$ art of simultaneously pursuing both a financial and a social return on investment (the double bottom line)." Social Enterprise Terminology, INST. FOR SOC. ENTREPRENEURS, https://www.socialent.org/ Social_Enterprise_Terminology.htm [https://perma.cc/LJM6-4RGX] (emphasis in original).

126. See Mitch, Tipping the Scales of Justice: The Role of the Nonprofit Sliding Scale Law Firm in the Delivery of Legal Services, 20 N.Y.U. J. LEGS. \& PuB. POL'y 375, 381 (2017).

127. But see Hila Keren, Women in the Shark Tank: Entrepreneurship and Feminism in a Neoliberal Age, 34 COLUM. J. GENDER \& L. 75, 93-94 (2016) (discussing why women have more difficulty than men in the entrepreneurial arena).

128. Ashoka is an organization that links social entrepreneurs across the globe to "collaborate to transform institutions and cultures worldwide so they support changemaking for the good of society." ASHOKA, supra note 9.

129. Beyond Legal Aid, supra note 114. 
Previous generations of public interest lawyers viewed for-profit organizations with skepticism, ${ }^{130}$ often dismissing for-profit ventures as less committed to social justice. While some lawyers think that charging fees for social justice work is inappropriate, there are others today who believe that for-profit models can achieve the same goals as their nonprofit counterparts. Social justice-minded firms can either charge low fees to social justice clients, combine free social justice work with regular fee-paying clients, or both. Like all small businesses, some for-profit law ventures fail. ${ }^{131}$ So, such entities require a good business plan to ensure long term sustainability, especially as technology disrupts traditional practice models. Lawyers can establish viable for-profit social justice law practices, particularly if they utilize technology in the delivery of their services. 132

There is no one right way for an entrepreneurial lawyer to work to promote social justice. What is most important is the vision for innovation and the commitment to advancing a social justice cause. This sometimes requires lawyers to step out of their legal roles and think like entrepreneurs. Social entrepreneurship, with its focus on business plans and profits as key components of sustainable social justice work, is changing critical lawyers' visions of how they can engage in social justice legal practice. 133

130. Cf. Trubek \& Kransberger, supra note 7, at 221 (indicating a shift in the makeup and viewpoints of the public interest bar and a new willingness to accept private sector support).

131. See Matt Mansfield, STARTUP STATISTICS - The Numbers You Need to Know, SMALL Bus. TRENDS (Mar. 28, 2019), https://smallbiztrends.com/2019/03/startup-statistics-smallbusiness.html [https://perma.cc/J7TU-CCTB] (discussing how out of all small businesses started in 2014, the startup failure rate at four years is about forty-four percent).

132. See Richard Granat \& Stephanie L. Kimbro, The Teaching of Law Practice Management and Technology in Law Schools: A New Paradigm, 88 CHI.-Kent L. Rev. 757, 758-59 (2013) (discussing the need for law school courses on legal business management, particularly updated courses on the use of technology).

133. Researchers at George Warren Brown School of Social Work at Washington University in St. Louis developed a Sustainability Framework and Assessment Tool for business management. The tool assesses Environmental Support - garnering enough support within and outside the organization to garner attention and resources that will help your organization succeed; Partnerships relationships between your organization or program and its stakeholders so they can rally your base, leverage resources, and build awareness of what you offer; Organizational Capacity - having enough resources and support to properly manage your internal operation; Program Evaluation evaluating your program and documenting its impact on all its beneficiaries; Program Adaptation changing course of action to ensure the program continues to be responsive and effective to comply with its mission; Communications - targeted and strategic communication with stakeholders and the public so they understand what you do and why it matters; and Strategic Planning - planning the direction, goals, and plans to implement your organization or program's mission. For definitions and explanations of sustainability capacity and other components such as environmental support, funding stability, and strategic planning, see Understand Sustainability, ProGRAM SUSTAINABILITY ASSESSMENT TOOL, https://www.sustaintool.org/understand/ [https://perma.cc/3TGQ-ZAS5]. For an explanation of the methodology that led to the framework, see Sara F. Schell, Douglas A. Luke, Michael W. Schooley, Michael B. Elliott, Stephanie H. Herbers, Nancy B. Mueller \& Alicia C. Bunger, Public Health Program Capacity for Sustainability: A New Framework, 8 ImPLEMENTATION SCI. 15 (2013). 
It is crucial for any lawyer who is establishing a law practice to develop business plans that envision long-term sustainability. One aspect of sustainability is marketing to expand demand for services. In today's world of legal self-help and form automation, lawyers must communicate their value to consumers. Social justice movements often need legal expertise, and proper marketing can help lawyers sustain social justice practices. Professor Elizabeth Chambliss describes the type of messaging that emphasizes lawyers' value for social movements as marketing to increase demand for law. 134 This type of communication is essential for the development of networks. Chambliss explains that in the legal profession there are "few mechanisms for national coordination and branding." 135 In order to develop sustainable practices, lawyers must communicate the importance of what they offer, including the prospect that sometimes nontraditional lawyering is the best solution for certain legal needs. ${ }^{136}$

Marketing and branding also let potential contributors know about an organization. Law for Black Lives uses tools such as video and social media to engage lawyers and non-lawyers alike. 137 Their mission statement communicates their commitment to work alongside "legal workers" who are "committed to building a responsive legal infrastructure for movement organizations." 138 They make clear that their approach seeks to cultivat[e] a community of legal advocates trained in movement lawyering."139 Their mission statement makes clear that Law for Black Lives understands the connection between access to social justice and collaboration between lawyers and leaders of impacted communities. The rise of social media opens up space for new marketing tactics. For example, TIME'S UP connects lawyers, the community, and clients who have experienced sexual harassment. 140 TIME'S UP helps locate legal services consumers through its national system and links them with lawyers and local partner organizations.

The way critical lawyers establish and describe their relationships becomes important when seeking resources and ensuring financial viability. Lam Ho promotes Beyond Legal Aid as offering 'alternative legal aid.' He argues that his community approach to legal assistance is more accessible than the approach of traditional legal aid organizations. This rhetoric of linking clients with communi-

134. See Elizabeth Chambliss, Marketing Legal Assistance, 148 DAEDALus 98, 100-02 (2019).

135. Id. at 100 .

136. See Sandefur, supra note 104.

137. See Law for Black Lives (@Law4BlackLives), FACEBOOK, https://www.facebook.com /Law4BlackLives/ [https://perma.cc/6QFU-HE6Z]; Webinars, LAw FOR BLACK LIVES, http://www .law4blacklives.org/webinars [https://perma.cc/Q3AT-WPZY].

138. About Us, supra note 13.

139. Id.

140. TIME'S UP Legal Defense Fund - Helping to Break the Cycle of Silence and Isolation, IMPACT FUND (Mar. 26, 2019), https://www.impactfund.org/social-justice-blog/timesup [https://perma.cc/G9C5-V58M]. 
ty resources does more than just inform clients about how Beyond Legal Aid works, it also helps build ongoing relationships with clients.

\section{Today's Contributors}

The quest for social justice today engages a variety of people. This diverse set of actors includes advocates, donors, and supporters. They play different roles in contributing to causes, and as a result have different expectations about the effectiveness of their contributions. The critical lawyer uses technology and social media to identify and reach contributors who were not previously part of the philanthropic landscape. This approach mirrors the social entrepreneurship models that encourage market participation, as well as traditional donors. Social justice law practice no longer conforms only to the nonprofit public interest model but includes innovations that generate revenue and leverage volunteerism. Leaders of these law practices are developing new approaches to ongoing fund development to sustain their work. TIME'S UP is largely funded by Hollywoodbased donors. ${ }^{141}$ These social justice advocates use technology and personal connections to assist women's groups and local clients. While not every social justice advocate has celebrity power behind them, they do have the conviction of social justice causes. They are experimenting with generating income from clients, partnering with NGOs, and utilizing online resources.

Social justice advocates can now rely on social media and platforms such as GoFundMe to raise money for causes. Technology is now crucial to fundraising because it has expanded who can contribute to philanthropy. Individuals who care about a cause will contribute small amounts because they understand that pooling their money can make a difference. For example, the ACLU raised \$24 million from over 350,000 individual donors in the days after the first Muslim ban in 2017 to support the work of representing detained immigrants at U.S. airports. ${ }^{142}$ When immigration officials began separating children from their immigrant parents at the U.S.-Mexico Border in the summer of 2018, the Refugee and Immigrant Center for Education and Legal Services (RAICES), an otherwise obscure nonprofit legal organization in Texas, raised $\$ 10$ million through a social media campaign. ${ }^{43}$ RAICES used the money to help pay for immigrant detainee bonds to reunite these children with their parents. ${ }^{144}$ Online platforms allow

141. Alix Langone, These Are the Biggest Donors to Hollywood's Record-Breaking \#TimesUp Campaign, MoNEY (Jan. 18, 2018), https://money.com/times-up-go-fund-me-donations/ [https://perma.cc/M52K-6FSH].

142. Liam Stack, Donations to A.C.L.U. and Other Organizations Surge After Trump's Order, N.Y. Times (Jan. 30, 2017), https://www.nytimes.com/2017/01/30/us/aclu-fund-raising-trumptravel-ban.html [https://perma.cc/6XY9-69HY].

143. Olivia P. Tallet, Facebook Campaign to Reunite Immigrant Kids in Texas with Parents Raises Over \$10 Million, Hous. CHRON. (June 20, 2018, 7:25 PM), https://www.chron.com/news/ houston-texas/houston/article/Facebook-campaign-to-reuuite-immigrant-kids-in-13011345.php [https://perma.cc/D7MP-A4KT].

144. See id. 
people to donate from their couch without picking up a pen or checkbook. And small contributions can become significant funding sources when aggregated through targeted campaigns. Small, frictionless donations help bring in new sources of funding and raise the profile of organizations advocating for social justice. 145

Taken together, small contributors can function as an 'aggregate donor,' and once donors give, they often want to be involved in the activity of the organization. The involvement of new contributors has sometimes caused long-standing organizations to debate their role. In many ways, successful funding through online platforms gives new donors the ability to move organizations towards more activist agendas. The influence of donors on the ACLU helped the organization, which traditionally focused on civil rights and civil liberties, have a stronger presence in the immigration rights space. 146 The New York Times Magazine reported that following the 2016 presidential election, the ACLU's Membership soared and donations went from \$5 million to almost \$120 million. ${ }^{147}$ This increased investment has permitted the organization to devote additional resources to pursue more political strategies to protect civil rights and civil liberties. ${ }^{148}$ These new approaches, including voter rights campaigns and involvement in electoral races, have energized and increased the ACLU's donor base, but they have also triggered an internal debate within the ACLU about the organization's proper role. ${ }^{149}$ This conversation within the organization signals that there are critical practices that are pushing the boundaries of traditional public interest law practice. 150

Contributors may also become more involved by engaging in pro bono work. In pro bono work, lawyers donate their time by providing legal counsel to nonprofit organizations and social justice clients and causes. Beyond Legal Aid, Law for Black Lives, and TIME'S UP rely on pro bono lawyers to do much of their legal work. Lawyers taking on legal work to support social justice organizations can develop skills they may use for their law firm's bigger clients. Much of the pro bono work done by larger law firms and general counsel offices is in partnership with social justice law practices, and both parties benefit. ${ }^{151}$

145. In addition, celebrities who care about causes can help raise millions of dollars through social media and online fundraising platforms. See, e.g., Josh Peter, J.J. Watt's Hurricane Harvey Relief Fund Closes with Over \$37 Million Raised, USA TODAY (Sept. 15, 2017, 7:27 PM), https://www.usatoday.com/story/sports/nfl/texans/2017/09/15/jj-watt-hurricane-harvey-relief-fundends/672397001/[https://perma.cc/3RLZ-U3YZ].

146. Lovell, supra note 55.

147. Id.

148. See id. (discussing the ACLU's involvement in educating voters about candidates in local elections).

149. Id.

150. Id.

151. See Steven Boutcher, Lawyering for Social Change: Pro Bono Publico, Cause Lawyer- 
Social justice law practices must demonstrate their effectiveness in this period of experimentation and exploration. For example, the Legal Services Corporation requires evidence-based documentation as a condition of its grants. 152 States also require such data to track the progress and effectiveness of their grantees. ${ }^{153}$ Many law schools also collect client data from their clinics through law practice management tools. ${ }^{154}$ This data can be used to describe the impact of clinical work and inform policy. TIME'S UP is starting a new project on research about sexual harassment funded through a substantial grant. 155 Effectiveness research is essential to new social justice practices, since they market themselves as improving people's lives. ${ }^{156}$ Contributors expect evidence of the value of their investment. ${ }^{157}$

As practitioners seek to use the tools of empirical research and collaborate with social scientists, challenges can arise. Social science researchers set out to collect and analyze data that can reveal problems with the strategies used by the advocates. ${ }^{158}$ Critical lawyers are recognizing and working to overcome these barriers. Law schools are hiring professors who understand empirical research methods. ${ }^{159}$ The American Bar Foundation is fostering partnerships between social scientists and lawyers to produce more research on civil legal services. ${ }^{160}$

ing and the Social Movement Society, 18 MobilizATIOn: An InT'L Q. 179, 191-93 (2013) (discussing social movements' use of pro bono work); Trubek, supra note 28.

152. See 45 C.F.R. $\S \S 1600-44$ (2019); 2020 Basic Field Grant Terms and Conditions, LEGAL SERVS. CORP., https://www.lsc.gov/grants-grantee-resources/grantee-guidance/grantassurances/2019-basic-field-grant-terms-and-conditions [https://perma.cc/UMF6-HVS2].

153. See Memorandum from Jonathan W. Vickery, Assoc. Dir. \& Dir. of Grants, to Tex. Access to Justice Found. Grantees (Jan. 16, 2019) (on file with Tex. Access to Justice Found.); CAL. Rules of State Bar, tit. 3, § 3.681 (2007); Grants, Tex. Access to Justice Found., http://www.teajf.org/grants/index.aspx [https://perma.cc/JJ6A-KR43]. (2013).

154. See Jeanne Charn \& Jeffrey Selbin, The Clinic Lab Office, 1 WIS. L. Rev. 145, 162

155. See Zraick, Tina Tchen, supra note 24. (2019).

156. See Elizabeth Chambliss, Marketing Legal Assistance, 148 DaEdalus 98, 100-02

157. See Lovell, supra note 55 (quoting ACLU Executive Director Anthony Romero saying, "People did not give to the A.C.L.U. for us to put that money into a bank account. If at the end of this year what I have to show to all these people rushing to become members of the organization is a better balance sheet, I'd get properly skewered. Shame on us if we don't find a way to put that money to use.").

158. See Louise Trubek \& Richard Abel, Law \& Soc'y, Committee on LSA's 2nd Half CENTURY: FinAL REPORT (2014), https://www.lawandsociety.org/docs/Final_2HC_Report.pdf [https://perma.cc/QXY4-MFU3].

159. See Blake Edwards, The Age of the PhD Law Professors Is Upon Us, Study Says, BloOMBerg L.: Big L. Bus. (Feb. 19, 2016), https://biglawbusiness.com/the-age-of-the-phd-lawprofessor-is-upon-us-study-says [https://perma.cc/2XZX-FUSC].

160. See Rebecca Sandefur, Access to Justice, A.B.A., http://www.americanbar foundation.org/research/project/106 [https://perma.cc/J4Z9-Z2K9]. 
And the Bellow Scholars Program helps law school clinicians support one another as they learn research methodology to capture the impact of their work. 161

IV.

\section{BUILDING THE ARCHITECTURE}

Democratizing approaches to law through collaborations and new resources is essential to critical law practice. Critical lawyers are creating an architecture that leverages their expertise to help clients and communities advance their social justice missions. This architecture is comprised of nodes within a geographic or interest community that are then linked with other relevant nodes. These connections are the networks. Technology facilitates the nodes and networks architecture by helping lawyers communicate with individuals in their own communities, connect with other social justice movements, and tap into peer support groups that provide training and personal sustenance. A nodes and networks structure produces sustainability, flexibility, and growth.

\section{A. Nodes and Networks}

Social scientists use social network analysis to explore the transfer and sharing of information through nodes and networks. ${ }^{162}$ Social network analysis helps identify relationships between 'knowledge possessing' people or organizations. The organizations or people are the nodes, and the relationships that tie them together form the larger network. ${ }^{163}$ Nodes and networks facilitate systems that allow greater communication, impact, and diffusion of decision-making about legal strategy. Nodes and networks are ways of organizing around common interests. Technology facilitates nodes and networks by helping to overcome geographic barriers and allowing linkages across communities and practices areas.

Today's critical lawyers are creating innovative practices using the nodes and networks model. Law for Black Lives links progressive lawyers and students across the country through webinars offering a common understanding of social justice work. 164 Online platforms can connect private practitioners, law students, and nonprofit lawyers. ${ }^{165}$ Beyond Legal Aid places lawyers with local NGOs in underrepresented communities. ${ }^{166}$ These lawyers link the community-based

161. Bellow SchOlar Program, https://sites.google.com/view/bellowscholars/home [https://perma.cc/WS67-QWKQ].

162. See Clifford D. Shearing \& Jennifer Wood, Nodal Governance, Democracy, \& the New 'Denizens,' 30 J. L. \& Soc'Y 400, 404-05 (2003).

163. For example, TIME'S UP Legal Defense Fund is housed at and administered by the National Women's Law Center Fund, which is located in Washington D.C. See TIME'S UP Legal Defense Fund, supra note 21.

164. See Webinars, supra note 137.

165. See id.

166. See E-mail from Lam Ho, supra note 72. 
nodes. ${ }^{167}$ Beyond Legal Aid has a central office where the lawyers meet one or two times a week for supervision and to handle the organization's administrative tasks. ${ }^{168}$ The network uses case management software and other mobile technology to link its different programs. ${ }^{169}$ TIME'S UP uses a connector network based in the central D.C. office to link clients all over the country with lawyers in their communities. 170

Technology facilitates the development of networks that encourage shared resources and peer support. It also allows local activity to flourish with the support of a national infrastructure. TIME'S UP's use of community-based organizations as resources for clients is possible through a nationally visible node that publicizes how to seek help. Once the client contacts a lawyer, the client can be linked with an organization that is knowledgeable about the client's community, thus providing peer support. Law for Black Lives connects widely dispersed clinics and communities. This setup allows law practices and local organizations to link together to advance common goals like reducing the carceral state. Combining local actions with a broad vision is essential for new social justice law practices. ${ }^{171}$ Technology has made geography less of a barrier to organizing collective action. It has made it easier for social justice advocates to work together on causes regardless of their practice setting or the organizational structure.

Many lawyers who work alone or in an isolated environment find themselves drawn to a network to help them build community. Lawyers and legal expertise are not spread evenly across the country. Professor Lisa Pruitt calls the gaps resulting from this unevenness "legal deserts." 172 Legal deserts are usually the result of rural isolation, though they are compounded in neighborhoods with low-incomes or language barriers. ${ }^{173}$ Coastal cities are crammed with nonprofits and lawyers, while the South and Midwest have substantially fewer assets. All three of the examples discussed in this article link dispersed lawyers with clients in geographically diverse communities, usually through community organizations. The community nonprofit is a partner to the institutional node. This model may be one route to creating sustainable organizations in legal deserts facilitated

167. See id.

168. See id.

169. See Beyond Legal Aid 2, supra note 118; Comment to authors from Lam Ho, Exec. Dir. \& Founder, Beyond Legal Aid (Sept. 2019) [hereinafter Beyond Legal Aid Comments].

170. See Lewis, supra note 24.

171. See David Cole, The Path of Greatest Resistance, N.Y. REV. OF BooKs (Feb. 7, 2019), https://www.nybooks.com/articles/2019/02/07/social-movements-path-greatest-resistance/ [https://perma.cc/VV43-L7S2] (discussing how the surge of social media to organize quickest can undercut the development of institutionally sustainable organizations); see also Stephen Manning \& Juliet Stumpf, Big Immigration Law, 51 U.C. DAvis L. REv. 407, 420-25 (2018) (discussing mass defense of immigration cases using techniques based on technology).

172. See generally Legal Deserts, supra note 83.

173. See id. at 118-19. 
by new technologies. ${ }^{174}$ Beyond Legal Aid's network is based in Chicago. However, the nodes and networks model allows it to consider expanding their reach throughout the Midwest.

Perhaps the most developed peer support network that critical lawyers can look to as a model is the global network of social entrepreneurs supported by Ashoka. ${ }^{175}$ Ashoka is an organization that connects social entrepreneurs across the world to learn about each other's work and find patterns that can be replicated in similar communities. ${ }^{176}$ Ashoka's tagline-'Everyone a Changemaker'encourages community organizers and leaders to build locally but connect globally to amplify their work. Ashoka programs exist in ninety countries. These programs find social entrepreneurs who are developing "system-changing innovations" to "solve deep-rooted social problems." 177 There are more than 3,500 Ashoka fellows who have a lifetime membership to a network of collaborators who help them develop and amplify their visions for improving the world. ${ }^{178}$ Lam Ho and Beyond Legal Aid have recently become part of Ashoka's network. Ho reports that the network has broadened his vision for the organization by exposing him to new collaborators across the globe.

Technology facilitates a new organizational structure based on nodes and networks, but some lawyers are cautious of technology's role. Lam Ho, for example, is hesitant about too much reliance on technology, particularly since many of his clients lack access to technology. ${ }^{179}$ Still, technology is essential for growth, and it allows national networks to link to under-resourced areas.

\section{B. Fostering Growth and Innovation}

Critical lawyers, practices, and networks need institutional encouragement, including training and support systems, to be effective. Law schools and peer support networks are now beginning to assume that role. Law schools can encourage social justice careers by offering curricula that intentionally question the interaction of law with underserved populations. They can also provide resources to support social justice-driven students in law school and post-graduation.

\section{Law Schools}

Law schools are central to the ability of social justice-oriented law students to continue on the path to meaningful careers. However, the relationship between legal education and social justice is contradictory. On the one hand, practitioners

174. But see Cole, supra note 171.

175. About Ashoka, AsHOKA, https://www.ashoka.org/en-us/about-ashoka [https://perma.cc /D9N9-7ZTR].

176. Id.

177. Id

178. Id.

179. See Beyond Legal Aid 2, supra note 114. 
need the knowledge, skills, and resources they can obtain from law schools. On the other, law schools primarily train students to respect and uphold a rule of law that can feel oppressive to members of marginalized communities.

Law schools face the contradictions of both supporting social justice values and teaching the conventional law school curriculum. Law schools must deliver legal education to produce a variety of lawyers, both students seeking conventional careers and students who want to challenge the status quo. Law school faculty and staff who care about social justice causes must find ways to channel their passion for helping to shape students into critical lawyers without alienating students who do not share the same vision.

Clinical legal education was an effort by law schools to address the contradiction. It was once perceived as the primary vehicle to expose students to social justice values and develop skills. ${ }^{180}$ By 1960, there were approximately thirtyfive law schools that included some legal aid activity in their programs, but only a fraction offered credit for student engagement in the activities. ${ }^{181}$ In 1959 , only five law schools had supervising faculty that received teaching credit for teaching a clinical course. ${ }^{182}$ Beginning in the 1960's and continuing through the 1990 's, student demand for more practically relevant law school experiences justified incorporating a practice component into legal education. 183 Clinical education in law schools was cemented primarily by third-party funders such as the Ford Foundation, which invested more than \$11 million between 1968 and 1978 to support clinics in more than one hundred law schools. ${ }^{184}$ This infusion of funds was temporary, which often meant that many of those who worked in the clinics did not have job security.

Clinical education, and experiential education more generally, exists in all ABA accredited law schools. ${ }^{185}$ However, at many law schools, clinical instruction depends on temporary grants, creating a reproduction of traditional hierarchies of legal practice. ${ }^{186}$ Those law schools that tenure or otherwise assume the cost of their clinical instructors often require that faculty who teach clinic also

180. Margaret Martin Barry, Jon C. Dubin \& Peter A. Joy, Clinical Education for this Millennium: The Third Wave, 7 CLINICAL L. REV 1, 12 (2000) ("The earliest forms of clinical legal education embraced the dual goals of hands-on training in lawyering skills and provision of access to justice for traditionally underrepresented clients.").

181. Id. at 10 .

182. Id.

183. Id. at 12 .

184. Id. at 18-19. The U.S. Department of Education operated a Title XI Law School Clinical Experience Program between 1978-1997, that infused over \$80 million dollars. Id. at 18.

185. In 2015, the ABA adopted Accreditation Standard 303(a) that requires law schools to offer their students at least six credit hours of experiential education. AMERICAN BAR ASSOCIATION Section of Legal Education \& Admissions to the Bar, ABA Standards and Rules of Procedure For Approval of Law Schools 2019-2020, 16 (2019).

186. See Minna J. Kotkin, Clinical Legal Education and the Replication of Hierarchy, 26 Clinical L. Rev. 287 (2019). 
comply with the same scholarship requirements as non-clinic faculty. 187 Those that do not may have less job security or status at their law school.188 The tradeoff for cementing clinical education in a law school has largely meant that faculty teaching clinics have to spend less time on social justice work and more time on traditional faculty functions such as scholarship, non-clinical teaching, and law committee work. ${ }^{189}$ It should therefore not be surprising that recent critics of clinics argue that they are losing their social justice value by reducing the attention paid to disadvantaged communities. 190

In a recent article, Professor Deborah Archer argues that law school clinics have shied away too much from litigation. Clinics "should expose students to the transformational potential of integrated advocacy - strategic litigation, community organizing, direct action, media strategies, and interdisciplinary collaboration." 191 Archer laments that clinical faculty today focus primarily on teaching in the context of individual representation and do not sufficiently engage in teaching skills necessary to engage in political lawyering. 192 The professor describes 'political lawyering' as teaching law through a "systemic reform lens in case selection, advocacy strategy, and lawyering process, with a focus on legal work done in service to both individual and collective goals." 193 She describes political lawyering not as partisan, but as an engagement of lawyers to help disenfranchised communities to assert their power. ${ }^{194}$ Professor Archer therefore argues for an expanded view of the skills and approaches to clinical education to advance social justice advocacy. ${ }^{195}$

The contradictions in legal education may be most apparent to law students interested in social justice careers. Critical lawyers struggle to reconcile the useful skills and knowledge they are gaining in law school with their belief that much of what they are learning does not reflect the world as they know it or as they wish it to be. Saru Jayaraman at the Restaurant Opportunities Center, a TIME'S UP collaborator, mentions how her law school education discouraged her commitment to social justice practice. ${ }^{196}$ She views some of the teaching in

187. Id. at $290-91$.

188. See Bryan L. Adamson, Calvin Pang, Bradford Colbert, Kathy Hessler, Katherine Kruse, Robert Kuehn, Mary Helen McNeal \& David Santacroce, Clinical Faculty in the Legal Academy: Hiring, Promotion and Retention, 62 J. Legal Educ. 115, 126-31 (2012) (discussing the various models for clinical faculty in U.S. law schools).

189. Id.

190. See, e.g., Kotkin, supra note 186.

191. See Deborah Archer, Political Lawyering for the 21st Century, 96 DENV. L. REv. 399, 402 (2019).

192. Id. at $424-28$.

193. Id. at 401-03.

194. See id. at 409-10.

195. See id. at 428-34.

196. Spencer Bowen, Althea Lyness-Fernandez \& Mai Sistla, Fall 2019 Journal: A Conver- 
law school as having sexist and racist messages that support a status quo that is inconsistent with her values. ${ }^{197}$ She has been outspoken about her negative experience as a law student where she felt marginalized in her skepticism about the effectiveness of the rule of law to bring about social justice. 198 Marbre StahlyButts at Law for Black Lives recounts feeling so lonely, disconnected, and broken as a law student that she wondered whether going to law school was right for her. ${ }^{199}$ She says that despite this, she found clinical education allowed her to understand that law school could teach her the skills she needed to help the people she loved. ${ }^{200}$ Lam Ho views much of the work of Beyond Legal Aid as "unlearning" the lessons that lawyers are taught in law school, particularly in doctrinal courses. 201

Law schools offer education and skills development that simultaneously support and challenge law students who believe a legal education can equip them to be effective social justice advocates. Law schools can provide resources to law students and recent graduates considering social justice careers. Some of the positive steps law schools can take to support the formation of critical lawyers is to provide relevant curriculum and career counseling, loan forgiveness, and postgraduate fellowships that advance social justice goals. Critical lawyers are using social entrepreneurship and other innovative strategies to promote social justice, and their stories should now be part of the law school curriculum. Beyond Legal Aid attorneys, for example, speak in all Chicago-area law schools to provide information on new models. Lam Ho discusses how, as a student, the courses he took on social theory and his clinics helped him envision a career as a social justice lawyer. ${ }^{202}$ Law for Black Lives uses existing law school clinics and courses to provide legal assistance to community programs. They facilitate law school clinics' engagement with local social justice work and offer law students opportunities to support existing movements. ${ }^{203}$ Law schools that acknowledge both the legal liberalist public interest model and its critiques can combat the stereotype that law schools are elitist and value only commercial uses of legal expertise.

sation with Saru Jayaraman, Berkeley PuB. PoL'y J. (Oct. 21, 2019), https://bppj.berkeley .edu/2019/10/21/fall-2019-journal-a-conversation-with-saru-jayaraman/ [https://perma.cc/6XN396W4] ("I always say I find law to be a particularly problematic degree because it's one of the few degrees where, as opposed to a degree meant to open many doors and avenues for you, law very much closes the doors because you go through law school and then you're told, 'Well, you have to practice law in some form, you have to."').

197. See Telephone Interview with Saru Jayaraman, supra note 116.

198. Id

199. See Telephone Interview with Marbre Stahly-Butts, supra note 17.

200. Id

201. Beyond Legal Aid Comments, supra note 169.

202. See Beyond Legal Aid 2, supra note 118.

203. Telephone Interview with Erica Perry, P'ship Dir., Law for Black Lives (May 1, 2019). See also Clinical Cohort, supra note 112. 
Curriculum innovation is critical for the development of new social justice practices. Recent curricular innovations emphasize technology and entrepreneurship for social justice. ${ }^{204}$ For example, the Public Interest Technology University Network is an interdisciplinary university effort to engage technology to address public interest goals. ${ }^{205}$ While the current conversation about entrepreneurship in the legal profession focuses on preparing lawyers to counsel entrepreneurs, a shift is occurring. Educators have become more aware of the fact that most lawyers operate as solo or small firm practitioners, settings that require business skills. The same business skills are required to launch nonprofit organizations. A recent article recommends that law schools offer more information and exposure to the wide variety of professional options that now exist for law students. ${ }^{206}$ That information can enable the students to envision a career that will integrate their personal and professional values.

Law schools can be key contributors to reducing financial barriers for lawyers who want to build social justice law practices. On average, law students graduate with an education debt ranging between $\$ 100,000$ and $\$ 200,000 .^{207}$ Well-funded law schools support public interest work in the summer and also through loan forgiveness plans for graduates who meet a low-income threshold and work in the public interest sector. ${ }^{208}$ Lam Ho reports that he just paid off his student loans, including his undergraduate debt, after ten years of enrollment in Harvard Law School's loan forgiveness program. ${ }^{209}$ In 2011, federal loan forgiveness programs began offering options accessible not only to individuals who work at nonprofits or government but also to those who work in the private sector. These programs permit reduced monthly loan payments for lawyers regardless of their practice setting. ${ }^{210}$

204. A small number of law schools offer programming that merge technology, innovation and law. See, e.g., Lawyering in the Digital Age Clinic, Colum. L. ScH., https://www.law .columbia.edu/clinics/lawyering-in-the-digital-age-clinic [https://perma.cc/L6JX-SPZT]; Legal Design Lab, STAN. L. SCH., http://www.legaltechdesign.com/ [https://perma.cc/MR9T-8DXS]; New Economy Law Center, VT. L. ScH., https://www.vermontlaw.edu/academics/centers-andprograms/new-economy-law-center [https://perma.cc/VEA3-RBUD].

205. See Natasha Singer, Top Universities Join to Push 'Public Interest Technology,' N.Y. TimES (Mar. 11, 2019), https://www.nytimes.com/2019/03/11/technology/universities-publicinterest-technology.html [https://perma.cc/G74U-DHA9].

206. See Bliss, supra note 68.

207. See Greg Depersio, Is Going to Law School Worth It Anymore?, InVESTOPEDIA (Oct. 28, 2019), https://www.investopedia.com/articles/personal-finance/082416/going-law-schoolworth-it-anymore.asp [https://perma.cc/5SJB-YSVW]; Which Law School Graduates Have the Most Debt?, U.S. NEws (2019), https://www.usnews.com/best-graduate-schools/top-lawschools/grad-debt-rankings [https://perma.cc/N4QK-5G6Y].

208. See Loan Repayment Assistance Programs (LRAP), A.B.A., https://www.americanbar.org/groups/center-pro-bono/resources/directory_of_law_school_public_ interest_pro_bono_programs/definitions/pi_lrap/ [https://perma.cc/XL99-E9V̄E].

209. See Beyond Legal Aid Comments, supra note 169.

210. The PAYE and REPAYE programs for private sector workers cap loan payments at 
Another example of how law schools support social justice work is by encouraging post-graduate opportunities. These programs, in the forms of fellowships or law firm incubator programs, serve as a transition between law school and practice. Ho at Beyond Legal Aid and Stahly-Butts at Law for Black Lives relied on post-graduate fellowships for income and support as they developed their organizations. ${ }^{211}$ However, many fellowships and loan forgiveness programs require recipients to work for nonprofits. Critical lawyers interested in forprofit models and innovative experiments may be left out if they cannot find a nonprofit willing to take chance on their ideas. Law schools should encourage fellowship programs to expand beyond traditional nonprofit public interest jobs. Post-graduate fellowship programs have been slow to buy into entrepreneurial efforts and mainly focus on supporting fellowships in established nonprofit organizations. ${ }^{212}$

\section{Peer Support}

It is important for lawyers working in social justice settings to participate in peer support groups. They can rely on these groups for moral support and use them as a learning community. Peer support takes a variety of forms. TIME'S UP facilitates cross-organization collaboration through its network of partner organizations that support women in the workplace. ${ }^{213}$ Law for Black Lives organizes special cohorts of lawyers and activists through its fellowship programs ${ }^{214}$

$10 \%$ of the borrower's income, but they only forgive the balance of the borrower's loans after twenty or twenty-five years of payments. See PAYE vs REPAYE: Pay As You Earn Student Loan Repayment Plans, DEBT.ORG, https://www.debt.org/students/obama-pay-as-you-earn/ [https://perma.cc/JYN8-8KR2].

211. See Beyond Legal Aid 2, supra note 118; Telephone Interview with Marbre StahlyButts, supra note 17.

212. Of the fourteen post-graduate fellowships awarded in 2019 at UCLA, thirteen funded work at public interest organizations and one at the Public Defender's Office in Charlotte, North Carolina. See UCLA Law Awards 14 Post Graduate Public Service Fellowships, UCLA L. (July 29, 2019), https://aw.ucla.edu/news-and-events/in-the-news/2019/07/ucla-law-awards-14postgraduate-public-service-fellowships/ [https://perma.cc/3Q4H-7K9Q]. Columbia Law School lists eleven post-graduate fellowships on its website, and all require a focus on either public interest, government, or human rights. See Fellowships Exclusively for Columbia Law Grads, Colum. L. SCH., https://www.law.columbia.edu/social-justice/students/careers-public-service/postgraduatefellowships/current-fellowships [https://perma.cc/3QWG-U8TZ]. Post-graduate fellowships at University of Texas at Austin School of Law limit "new alumni to work with non-profit legal organizations and public defender offices." Postgraduate Fellowships, WiLliam Wayne Just. CTR. FOR PUB. INT. L., U. OF TEX. AT AUSTIN SCH. OF L., https://law.utexas.edu/publicinterest/type/postgraduate-fellowships/ [https://perma.cc/ZFT2-HLAR].

213. See Our Partners, TIME's UP Now, https://timesupnow.org/work/our-partners/ [https://perma.cc/T8CZ-WTGN].

214. Law for Black Lives offers lawyers and legal workers six-month fellowships to incubate ideas to build safe and sustainable communities. 2019 Law For Black Lives Fellowship, LAw FOR BLACK LIVES, http://www.law4blacklives.org/2019-fellowship [https://perma.cc/ZE9VV7LU]. 
and its clinical cohort. 215 Beyond Legal Aid connects lawyers and clients who work collaboratively on social justice campaigns. ${ }^{216}$ Social justice practices need safe places where all types of models can convene for support and knowledge sharing. Peer support communities are valuable networks for post-law school innovation and support.

The peer support model helps link law schools, practitioners, and activists. The Network for Justice, a pilot project based in California, seeks to connect academics to community activists, social justice lawyers, and policy makers. ${ }^{217}$ The project has an online platform where Latinx communities can connect with one another and share information and research. The group connects communities in the rural Central Valley with resources in larger cities such as Los Angeles, San Jose, and San Francisco. The project can help geographically isolated Latinx communities effectively access information and collaborate on law and policy initiatives. The nodes and networks approach permits the construction of a flexible, sustainable, and technologically advanced architecture.

In 2017, Law for Black Lives announced fellowships for lawyers, paralegals, law students, jailhouse lawyers, or community organizers who were developing legal strategies to advocate for Black lives and who work for organizations led by or centered on Black lives. ${ }^{218}$ The goal of the fellowship, organized in collaboration with Movement Law Lab, is to identify leaders who can scale up or increase the impact of a successful project to advance movement lawyering. The fellowship creates a cohort of leaders who support each other in their efforts to empower communities by increasing their ability to protect themselves, by democratizing law, and by creating new structures and opportunities that respond to the particular needs of their communities. The fellows are part of the Law for Black Lives peer support network. In exchange for this peer support, fellows develop trainings or written resources that the Law for Black lives network can use.

The sliding scale law firm listserv, organized by Mitch, a professor at the University of Wisconsin law school, is a peer support group that connects and supports sliding scale nonprofit law firms. ${ }^{219}$ Sliding scale law firms are nonprofit organizations that base their fees for legal services on the client's in-

215. About the Cohort, LAW FOR BLACK LIVES, http://www.law4blacklives.org/new-page [https://perma.cc/858V-3M9G].

216. E.g., Cmty. Activism Law All. (CALA), CALA Annual Report FY2018, at 11-12, 21 (2018), https://docs.google.com/presentation/d/e/2PACX-1vQSecuWQva tlU5klICxRCw 1ZrS3RF-hCyiVcNOI1sIxgkV-pmat_iQohctpvMtWW1uRcO9JnR9Z_2u/pub?start=true\&loop $=$ false \&delayms $=3000 \&$ slide=id.g4321a7b48c_16_0 [https://perma.cc/C5ZC-P5BW].

217. See NETWORK FOR JUST., https://network-for-justice.mn.co/feed [https://perma.cc /VE63-M8MV].

218. Legal Innovators Fellowship, LAw FOR BLACK LIVES, http://www.law4blacklives.org /legal-innovator-fellows/ [https://perma.cc/R3BW-K8ZL].

219. See Mitch, supra note 126 , at 379. 
come. ${ }^{220}$ Charging reduced legal fees through a nonprofit subsidy has become popular amongst critical lawyers for a variety of reasons. If the nonprofit is a charitable organization, attorneys can raise funds to subsidize the costs of legal work for clients who cannot pay the full cost of the service. The nonprofit model is enticing to law school graduates because they can qualify for the Public Service Loan Forgiveness Program and have the balance of certain federal student loans forgiven over time so long as they work for a nonprofit organization. 221

Law schools have initiated several successful cross-law school communities that focus on supporting lawyers and scholars advancing social justice. The Inter University Consortium on Poverty Law (the "Poverty Consortium") and the Law School Consortium Project (the "LSCP") are two examples of law school-based peer support networks. ${ }^{222}$ The Poverty Consortium started with three law schools in 1989 and expanded to thirty schools with Ford Foundation funding. ${ }^{223}$ It focused on peer exchanges to link poverty law teaching and scholarship to poverty law advocacy. ${ }^{224}$ LSCP linked law schools with community lawyers, with special emphasis on minority communities. 225 The group was founded by four law schools and expanded to seventeen with support from the Open Society Institute, and it provided training, mentoring, and other support to solo and small firms practices. 226

Both the Poverty Consortium and the LSCP flourished when funding was available. 227 Both organizations had a significant impact by infusing new ideas and practices in the profession, but neither group was able to sustain itself as a stand-alone entity. Members of the Poverty Consortium published a textbook that helped to establish poverty law as an area of study in the legal academy. ${ }^{228}$ There is now a poverty law section that is part of the American Association of Law Schools that hosts an annual conference and communicates via a listserv. 229

220. For more on sliding scale law firms, see $i d$. at 377.

221. See Public Service Loan Forgiveness, FeD. StUdENT AID, https://studentaid.ed .gov/sa/repay-loans/forgiveness-cancellation/public-service\#full-time-employment [https://perma.cc/HV5L-9EPS].

222. See Elizabeth Chambliss, Organizational Alliances by U.S. Schools, 80 FordHAM L. REV. 2615, 2631 (2012).

223. Id.

224. Id.

225. Id.

226. Id

227. Id

228. See Julie A. Nice \& Louise G. Trubek, Cases and Materials on Poverty Law: Theory and Practice (1997); Juliet Brodie, Clare Pastore, Ezra Rosser \& Jeffrey Selbin, Poverty Law: Policy \& Practice (2014); see also Louise G. Trubek, Social Justice Advocacy and Innovation: The Wisconsin Center for Public Representation 1974-Present, 25.2 GEO. J. POVERTY L. 221, 241-42 (2018).

229. See Section on Poverty Law, Ass'N OF AM. L. Schs., https://www.aals.org /sections/list/poverty-law/ [https://perma.cc/P977-8M3Y]. 
Similarly, members of the LSCP launched the first law firm incubator projects that sparked the development of similar programs across the globe. ${ }^{230}$ Today, the ABA lists more than forty of these programs on its website. ${ }^{231}$ While sustainability is always a challenge for social justice projects, their permanence is less important than their role in initiating and publicizing the development of peer support networks.

More recent law school-initiated efforts focus on developing peer support networks for social entrepreneurs operating as solo practitioners or in small firms. ${ }^{232}$ These networks often take the form of law firm incubator programs. ${ }^{233}$ According to the 2016 Comprehensive Survey of Lawyer Incubators, there are now over sixty existing or planned incubator programs across thirty-three states and four countries. ${ }^{234}$ Incubator programs help lawyers across a variety of practice models address the needs of the poor through pro bono, low bono, and unbundled legal services. ${ }^{235}$ Sitting at the intersection of entrepreneurship, innovation and social justice, law firm incubator programs are critical for teaching lawyers the skills they need to build sustainable practices that serve a community.

New practices and social justice practitioners can also benefit from more scholarly law school-based peer support. Critical legal studies, for example, grew in the 1980s as an informal group of law teachers and students across the United States. ${ }^{236}$ Longstanding examples of student peer groups organized across law schools are the Cover Retreat 237 and Rebellious Lawyering Confer-

230. See Luz E. Herrera, Incubating Community Law Practices: Post Graduate Models For Lawyers Training \& Access to Law, 1 J. EXPERIENTIAL LEARNING 215, 220-24 (2015). See generally Deborah Howard, The Law School Consortium Project: Law Schools Supporting Graduates to Increase Access to Justice for Low and Moderate Income Individuals and Communities, 29 FordHAM URB. L.J. 1245 (2002).

231. See Lawyer Incubator Directory, A.B.A., https://www.americanbar.org/groups/delivery legal_services/initiatives_awards/program_main/program_directory/ [https://perma.cc/3TQA$\overline{\text { WURR}} \overline{\mathrm{R}}$.

232. See John Christian Waites \& Fred Rooney, What We Know and Need to Know About Law Firm Incubators, 67 S.C. L. REV. 503 (2016).

233. See Patricia Salkin, Ellen Suni, Niels Schaumann \& Mary Lu Bilek, Law School Based Incubators and Access to Justice: Perspectives from Deans, 1 J. EXPERIENTIAL LEARNING 202, 204 (2015) (describing the value of incubator programs for law school graduates and their contributions to access to justice, and naming some law schools with incubator programs).

234. A.B.A. Standing Comm. ON the Delivery of Civil Legal Servs., 2016 COMPREHENSIVE SURVEY OF LAWYER INCUBATORS 5 (2016), https://www.americanbar.org/content /dam/aba/administrative/delivery_legal_services/ls_del_comprehensive_survey_lawyer_incubators .pdf [https://perma.cc/U8A3-TGTP].

235. See id. at 3-4, 38 .

236. Interview with David M. Trubek (Aug. 2, 2019) (on file with author).

237. 33rd Annual Robert M. Cover Retreat, YALE U., https://law.yale.edu/33rd-annualrobert-m-cover-retreat [https://perma.cc/KP2L-WYCG]. 
ence. 238 The Cover Retreat brings together law students, academics, and practitioners "to share their experiences, educate on the complexities and nuances of public interest law, network and reinvigorate their commitment to this important work." 239 The Rebellious Lawyering Conference began at Yale more than twenty-five years ago. It is now the largest student-run public interest conference in the United States. It "seeks to build a community of law students, practitioners, and activists seeking to work in the service of social change movements and challenge the hierarchies of race, wealth, gender and expertise." 240

Today's social justice-inspired lawyers understand that the architecture of legal advocacy has to use law school resources, establish peer support connections, and foster strategies for entrepreneurial growth. This new architecture requires law schools, bar associations, and philanthropists to re-think their strategies for reducing inequality through law.

$\mathrm{V}$.

\section{CONCLUSION}

This article offers an overview of the theoretical foundations and the environmental factors that inform critical lawyers. Many of these lawyers are emboldened by the racist, sexist, and xenophobic policies and sentiments of the Trump administration, and they are encouraged by the political awakening occurring among moderates around issues of race, gender, immigration, and inequality. 241 They are seizing the moment to move beyond outdated models of public interest law that no longer fit our technology-driven, diverse world. Some of these lawyers are tapping into their identities to help advocate for similarly situated individuals. The current cadre of social justice-inspired lawyers are part of a larger cohort of individuals who believe that it is time for previously marginalized ideas to become mainstream. The legal liberal vision of how law can effectively produce a just society is outdated and ineffective. Critiques of that vision now serve as a basis for new practice methods. Critical lawyers, in alliance with community organizations and clients, are finding new ways to use legal resources to facilitate a more just society.

The practices we highlight are reconceptualizing how to use law to empower immigrants, to collaborate with women harassed at the workplace to tell their stories, and to fight back against mass incarceration. Partnerships with communi-

238. Rebellious Lawyering Conference 2019, YALE U., https://reblaw.yale.edu/ [https://perma.cc/SZ9D-Y5U4].

239. 32nd Annual Robert M. Cover Retreat, supra note 237.

240. Rebellious Lawyering Conference 2019, supra note 238.

241. See, e.g., David Brooks, How White Democrats Moved Left, N.Y. TIMES (July 25, 2019), https://www.nytimes.com/2019/07/25/opinion/white-liberal-democrats.html [https://perma .cc/7JR5-9V2U]; Ilhan Omar, Ilhan Omar: It is Not Enough to Condemn Trumps Racism, N.Y. TimES (July 25, 2019), https://www.nytimes.com/2019/07/25/opinion/ilhan-omar-trumpracism.html [https://perma.cc/TF43-2BJL]. 
ties and causes are democratizing how lawyers work with clients and communities. Broadening the funding base and working with activists is creating a more equal relationship between lawyer, cause, and client. Critical lawyers envision an architecture that permits cross-boundary relationships, collective action, and a more democratic utilization of law. The lawyers, practices, and architecture we describe contain the seeds of viable and scalable models to advance social justice in today's milieu. These practitioners' visions are not limited by traditional views on who can support their efforts or how to advocate. They understand that the emergence of a social justice architecture requires an entrepreneurial approach that engages a variety of donors, plugs into networks, and sustains itself through peer support. Law schools can be key transmitters of this architecture by supporting social justice efforts. They can provide space, administrative support, and more post-graduate entrepreneurial opportunities. These new critical lawyers are emerging as essential elements for the future of U.S. society. 